Ann. Génét. Sél. anim., I972, 4 (2), I83-2I5.

\title{
FIFTEEN YEARS OF OBSERVATIONS ON THE DWARF GENE IN THE DOMESTIC FOWL $\left({ }^{(}\right)\left({ }^{2}\right)$
}

\author{
Paul E. BERNIER and George H. ARSCOTT \\ Department of Poultry Science, \\ Oregon Agricultural Experiment Station, \\ Oregon State University, \\ Corvallis, Oregon 97331 (U.S. A.)
}

\section{SUMMARY}

Observations on dwarfism at the Oregon A. E. S. go back to 1952 but systematic study began in 1956. Dwarf mutants have been observed in Cornish and in two inbred Leghorn lines and were also obtained from a local hatcheryman.

A mosaic female for dwarfism and normal size was observed in the progeny of dwarf males mated to normal size females. This female is genetically dwarf since all progeny has been dwarf. A spur has developed on the larger shank. It is hypothesized that the polar body with the sex chromosome bearing the gene for normal size has reunited with one of the first two cleavage cells. .This has resulted in a half-dwarf female and a half-normal-size triploid neuter. Cytological analysis of blood and feather follicles has revealed no karyotypic abnormality.

A sex-linked recessive lethal has been observed in a dwarf male with exceptionnally high semen production. Half of the female embryos from carrier males die very early and are often misidentified as infertile. Dwarf males mated to normal females would be a common method of obtaining dwarf-laying stock but the disparity in size could possibly reduce fertility level in natural matings.

Male to female ratios of $I:$ I 5 and $I$ : Io gave until this year approximately 80 per cent fertility. A period as long as three or four weeks appeared necessary to reach that level of fertility although it continued to increase but slowly for 30-35 days. In the period I966-197 I males were moved directly from dark to lighted pens with the females. This year the males were first exposed to fifteen hours of light for a month before being placed with the females. Fertility has climbed much faster, reaching 90 per cent in 15 days, 95 per cent in 21 days but the ratio was still IM : IOFF.

Pure-line dwarfs kept in individual cages and reproduced by artificial insemination exhibited fertility and hatchability comparable to those obtained with normal size females.

In our genetic selection for hen-housed egg production on the basis of individual and family performance results were for a time disappointing. This apparently occurred because polygenes for hypothyroidism were segregating as a result of the inbreeding that accompanied our selection. -Age at first egg increased to 32.5 weeks but it has gradually decreased to 24.3 weeks in the current generation, which is still r.7 weeks later than in our $O S U$ Production Line.

Hen-housed egg production was also disappointing in a number of years but it began to show improvement in the last three generations. It is now 83.4 per cent as high as that observed in the Production Line at 40 weeks of age. Egg size has gradually increased. Body weight has not changed

(1) Technical Paper no. 3082, Oregon Agricultural Experiment Station. Supported in part by grantsin-aid from the American Poultry and Hatchery Federation and the Shaver Poultry Breeding Farms.

$\left({ }^{2}\right)$. Presented to the First Symposium on the Dwarf Gene in the Domestic Fowl, Tours, France, March 4 and 5, 1971, under the auspices of the Station de Recherches avicoles, I. N. R. A., Nouzilly, France. 
because of the restriction placed on it in our selection. It would very likely have changed as a correlated response to our selection for egg size.

Nutrition studies have been conducted with populations ranging from 240 birds in early years to over $\mathrm{I}, 200$ dwarf layers in more recent years in groups of 60 to a pen. We have determined that dwarf pullets, even after allowing for their delayed sexual maturity, require less feed to reach laying age. The nutrition studies have involved the influence of (1) calcium levels; (2) double the normal level of vitamin-trace mineral supplement; (3) protein levels up to $2 \mathrm{I}$ per cent; and (4) supplementation with methionine, lysine and linoleic acid.

Although egg production plateaued at the ${ }_{5} 5$ per cent protein level, egg size continued to increase up to $2 I$ per cent. The addition of .05 per cent methionine was found to increase egg production and egg weight significantly and to levels comparable to those observed with a 21 per cent protein diet. Currently a low level of Protamone is being fed to layers reared with and without a Protamone supplement, but the level had to be cut in half to .0r67 per cent as it depressed egg production.

Physiological studies have involved observation of the hypophyses, thyroid, adrenals and ovaries of both growing and mature dwarf females, and also a bioassay of hypophyseal homogenates in immature hypophysectomized rats. Although the thyroids of dwarf females were found to be smaller than those of normal birds at 7-I3 months of age it could not be ascertained from the bioassay that alterations in the pituitary thyrotropic activity are responsible for the thyroid disturbances in the dwarfs.

The pituitary bioassay results do not support the contention of accumulation of somatropic hormone in the pituitaries of dwarf birds. Observations on ACTH and on gonadotropin potency of the dwarf pituitaries were also made.

Observations on dwarfism at the Oregon Agricultural Experiment Station go back to 1952 when one of us (PEB) obtained a dwarf male (\# 4,OoI) in the progeny of a cross between a S. C. White Leghorn male and a Cornish hen. Dwarf female segregates have also been observed in our Cornish line. In I956 a dwarf Leghorn female was observed in the progeny of a cross between our OSU Production Line and a male of another strain. The comparatively large egg laid by that hen $(26 \mathrm{oz}+)$ aroused our interest in the economic potential of dwarfism in layers. This interest had been first kindled by the studies of BIRD and Sinclatr (I939) and of BYERLY (I94I) which demonstrated the tremendous influence of body size on feed requirements for egg production. The brief report of KEARL (I957), in which he showed that labor efficiency and increased egg production per hen were the main reasons for increased efficiency in egg production, and that actually there had been little if any improvement in feed efficiency of egg production in the preceding twenty years, firmed up this interest in investigating the economic potential of dwarfism still further. It was reasoned that one would possibly expect diminishing returns in searching for additional eggs and increased labor efficiency but that reduced feed consumption was definitely a most profitable avenue to explore. Decreased body size is of course assurance of decreased feed consumption. This has been taken advantage of through the gradual monopoly of Leghorns on egg production as well as the decreasing body size of many strains of layers. One day while explaining these facts to a group of visiting poultrymen and showing them some of our midget chickens, one of them, Mr. Barry Brownell, mentioned that he had a few such small chickens himself and that he would gladly give them to our station. This gift increased the size of our population of miniature chickens and really launched us on what has become an increasing research commitment at the Oregon Agricultural Experiment Station. Serendipity thus led us to what we think is a promising avenue in the continuing 
search for greater efficiency in egg production. The dwarf gene appears to have a relatively high mutation rate judging from our observations and the reports and correspondence received from various countries, the most recent being from Australia. It remains to be determined whether we are dealing in all these instances of sexlinked dwarfism with genes identical by descent or simply alike in state. HUTT (I959) predicted the dwarf gene should eventually be found in many breeds of Bantam fowl into which the mutant was probably incorporated over the years in light of its recurrence. We have continued to obtain a few dwarf segregates from an inbred line which, to our regret, because of limited facilities, we were forced to mix with our other dwarfs. We have subsequently hypothesized that some of these dwarf segregates were probably of the hypothyroid type described by CoLE (I966). They have complicated our selection program. Today we would like to review some of our findings under the headings of genetics, reproduction, genetic selection, nutrition and physiology.

\section{GENETICS}

In the first year of our more intensive studies, in I957, we established that the dwarf trait we were working with was determined by a sex-linked recessive gene, possibly homologous to that described by HuTT (I949, I953) in the New Hampshire breed. Correspondence with Dr Hurr indicated that he had yet another dwarf gene under study, this time in Single Comb White Leghorns. We have since determined that it was likely of the same origin as some of the birds donated to the Oregon Agricultural Experiment Station. HUTT (I959) in reporting his studies on dwarfism in

TABLE I

Relative performance of sex-linked dwarf layers and their normal sisters

Sixteen periods of 28 days. April r959-May 1960, BERnier and Arscott (I960)

Performances comparées de pondeuses portant le gène de nanisme lié au sexe et de leurs sceurs normales

Seize périodes de 28 jours. Avril I959-mai 1960, Bernier et Arscott (I960)

\begin{tabular}{|c|c|c|c|}
\hline & Normal & Dwarf & $\frac{\text { Dwarf }}{\text { Normal }} \times 100$ \\
\hline Number Aver. . . . . . . . . . & 118.3 & 118.5 & \\
\hline Body weight (lbs) $\ldots \ldots \ldots$ & 4.46 & 2.87 & 64 \\
\hline Sexual maturity (weeks) .... & 23.4 & 24.6 & 105 \\
\hline Feed consumed $(\mathrm{lbs}) \ldots \ldots$ & 6.27 & 4.13 & 66 \\
\hline Eggs produced p. bd. ....... & 13.39 & 11.13 & 83 \\
\hline Egg weight (ozs./doz.) $\ldots \ldots$ & 25.5 & 22.8 & 89 \\
\hline Specific gravity (coded) .... & 10 & 9.1 & 91 \\
\hline Livability $\% \ldots \ldots \ldots \ldots$ & 83 & 95 & 114 \\
\hline Lbs. feed & & & \\
\hline Ib. live weight $\ldots \ldots \ldots \ldots$ & 1.41 & 1.44 & 102 \\
\hline doz. eggs $\ldots \ldots \ldots \ldots \ldots$ & 5.62 & 4.45 & 79 \\
\hline doz. 24 oz. eggs ........ & 5.29 & 4.68 & 88 \\
\hline
\end{tabular}


both the Nere Hampshire and the Single Comb White Leghorn expressed skepticism on the economic future of the dwarf layer because of its reduced egg production and egg size. However he recognized the possibility that its feed consumption might compensate for the lower egg production and egg size. When this study of HurT was published we already had an experiment under way to compare the performance of I20 normal and I20 dwarf sister segregates from a mating of males heterozygous for dwarfism with normal females. We found, BERNIER (1960), and BERNIER and ARscotr (I96o), Table I, that dwarf hens did not lay as well as their normal size sisters and that their eggs were not as large but that their reduced feed consumption, when expressed on a per dozen of $24 \mathrm{oz}$. basis, made the dwarf layers not only competitive but superior.

These results encouraged us to continue our studies and to expand them by undertaking a genetic selection program as well as an investigation of the nutritive requirements of dwarf layers. We reasoned that the reduction in body size caused by dwarfism meant a reduction in maintenance requirements and therefore that a greater proportion of the feed intake would have to satisfy the requirements for egg production. In the first few years we had to combine our nutrition and selection studies because of limited facilities and numbers but as our enthusiasm grew we decided to undertake nutrition studies on a larger scale by substituting dwarf for normal size layers in our regular nutrition research program in the Poultry Department. It was also decided to produce the larger number of dwarf layers necessary for these nutrition studies by mating dwarf males to normal size females. This program has been continued since and in one year we were presented with a gift in the form of an unusual bird which we would like to introduce to you at this time.

\section{MOSAIC FOR DWARFISM}

A mosaic for dwarfism and normal size, this bird, we would like to remind you, is the progeny of a dwarf male and of a normal female. Phenotypically if it is a female it should be a dwarf but to our surprise we found it to be a half-sider, a mosaic or a case of lateral asymmetry as the illustrations clearly show (fig. I $a$-I $b$ ).

The mosaic is without question normal on its right side but dwarf on its left side. It has not been an exceptionally good layer but it has laid well and when mated to a dwarf male it has given exclusively dwarf progeny, both male and female in a I : I ratio. The large spur on the right leg has developed this last year. There is a sizeable catalog of mosaics in the poultry genetics literature which was reviewed by HOLLANDER (1944). What are the possible explanations for our half and half mosaic?

The most generally accepted hypotheses for lateral asymmetry in the domestic fowl are those proposed by CREW and MUNRo (1938, I939); a slight discrepancy in size, less than 4 p. Ioo, would be explained by the elimination of an autosome at the first cleavage division whereas a major discrepancy (IO-I5 p. IOO) would be the result of non-disjunction at the same stage, an autosome being lost from one side and gained on the other.

We cannot accept CREW and MUNRo's hypothesis of non-disjunction of an autosome to explain our case. The sex chromosome carrying the gene for normal size needs to be reintroduced into the zygote at the first cleavage. Non-disjunction of 
$Z^{d w}$ at the first cleavage would result in the absence of $Z^{a w}$ on one side and it would probably be lethal whereas $Z^{d w} Z^{d w}$ would probably not be a simple dwarf female.

So far we favor one hypothesis and Dr R. N. SHOFFnER, University of Minnesota (Personal communication) has offered another that is a possibility but a remote one in our estimation because of the two chance events it requires.
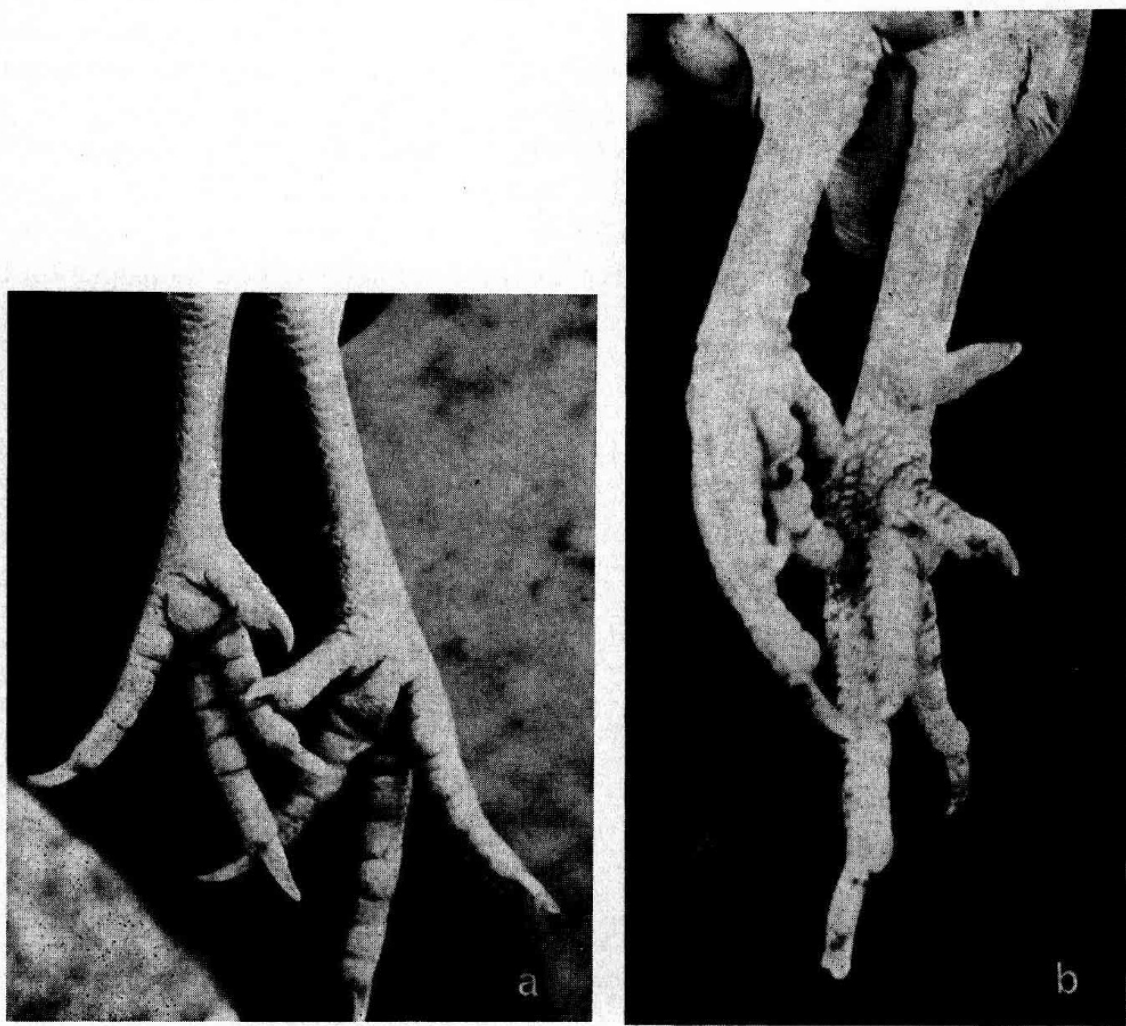

FIG. 1. - Legs of mosaic female

a) First observed at 16 weeks of age. Note spur bud and larger scales on right shank.

b) When three years of age with very well developed spur on right shank. Right shank $\mathrm{I} 2 \mathrm{~cm}$ long and left shank $9 \mathrm{~cm}$ long.

Pattes de la femelle mosaïque

a) Observées à 16 semaines d'âge. Noter le bourgeon d'ergot et les écailles plus grandes sur la patte droite.

b) A l'âge de 3 ans, avec un ergot bien développé sur le tarse droit. Tarse droit ayant $\mathrm{x} 2 \mathrm{~cm}$ de long et tarse gauche $9 \mathrm{~cm}$.

The hypothesis we favor is that the polar body carrying the large sex chromosome, $\mathrm{Z}^{+}$, and therefore the dominant sex linked gene for normal body size, since the dam was a normal-size female, reunited with half the zygote after the first cleavage. This would result in triploidy for the autosomes and diploidy for the $Z$ sex chromosome on the normal side, $A A A Z+Z^{d w}$, and simple diploidy on the dwarf side, or $\mathrm{AAZ}^{a w} \mathrm{~W}$.

The second possibility, suggested by Dr R. N. SHOFFNER, is that of non-disjunction of the $\mathrm{ZW}$ at the first metaphase (first polar body extrusion) resulting in the 
female gamete with a set of autosomes, A, and $\mathrm{Z}+\mathrm{W}$ sex chromosomes. This female gamete, $\mathrm{AZ}+\mathrm{W}$, fertilized by a dwarf male gamete, $\mathrm{AZ}{ }^{d w}$, would result in a zygote diploid for autosomes but trisomic for the sex chromosomes, $\mathrm{AAZ}+Z^{d w} \mathrm{~W}$. At the first or possibly some very early cleavage the chance segregation of the sex chromosomes could be $Z^{d w} \mathrm{~W}$ to one daughter cell and $Z^{+} \mathrm{O}$ to another daughter cell which followed by unilateral proliferation of these cells would result in one side, $Z^{d} w$, being dwarf 'as well as a genetic female, while the other side, $\mathrm{Z}+\mathrm{O}$, would be a genetic " neuter " of normal size. The endocrine control would originate from the left functional gonad or ovary. These two possible explanations are illustrated in fig. 2.

The critical observation will of course be to determine the karyotype of the mosaic on each of its two sides. So far a limited study of feather follicles and of blood cell cultures have not shown departure from the normal female karyotype of $\mathrm{ZW}$. We plan a detailed cytological study whenever we undertake an autopsy on this mosaic bird.
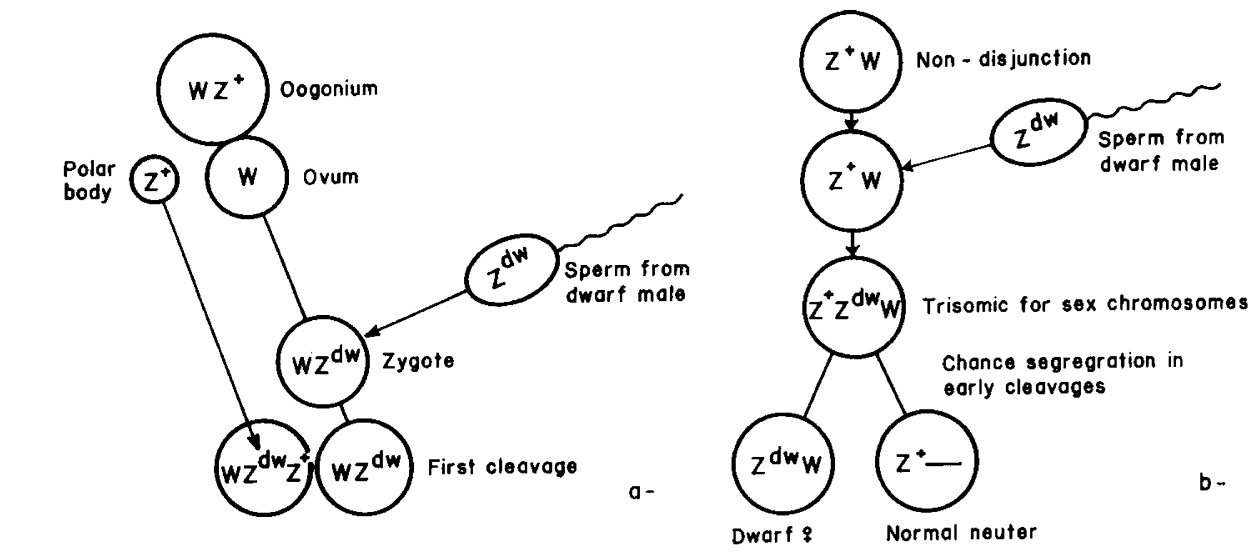

FIG. 2. - Possible explanations for the dwarf-normal mosaic fenale obtained from the mating of a dwarf male and a normal female

a) Reunion of polar body with first cleavage product.

b) Non-disjunction at Metaphase I in oogenesis.

Explications possibles de la femelle mosaïque naine-normale obtenue à partir de l'accouplement d'un mâle nain et d'une femelle normale

a) Réunion du globule polaire avec le produit du premier clivage.

b) Non-disjonction à la Métaphase I dans l'ovogenèse.

\section{SEX-LINKED RECESSIVE LETHAL}

In our genetic selection in the dwarf line, in I96I, we observed a sex-linked recessive lethal which probably would have gone unnoticed had it not been for isome unusual circumstance. Earlier we referred to the fact that we innocently had mixed birds possibly carrying hypothyroidism and sex-linked recessive dwarfism. As our intensive selection program progressed we necessarily inbred and this resulted in the segregation of the polygenes for hypothyroidism. These segregates were manifestedly poorer layers and many were non-layers while the males were often obese and difficult if not impossible to ejaculate. Chance favored us with a male that was an 
exceptionally heavy semen producer as well as easy to ejaculate. This male was used extensively in inseminating 50 dams and it sired 437 chicks. Throughout the brooding season we noted that there appeared to be an unusually large number of red combs in that brood of chicks. It turned out that the sex distribution was 297 males and I40 females or $68: 32$ or very close to the $2:$ I ratio expected on the basis of a sexlinked recessive lethal. The affected female zygotes apparently die very early, so early that it is often difficult to identify the egg as infertile or as early dead. It has not been possible as yet to determine the relationship of this sex-linked recessive lethal to the gene for dwarfism. Male \# 6266 was also heterozygous for the spontaneous chromosome translocation we have described earlier, BERNIER (I953, I960) and RYAN and BERNIER (I968), and it is likely that this heterozygosity may explain the excellent semen production. Table 2 shows the results obtained with male \#6 266 .

TABLE 2

A sex-linked recessive lethal in a dwarf male no. 6266, observed in 1961

Un létal récessif lié au sexe chez un mâle nain no 6266, observé en 1961

\begin{tabular}{|c|c|c|}
\hline & Number & Percentage \\
\hline No. of mates & 50 & 1 \\
\hline No. of eggs set $\ldots \ldots \ldots \ldots \ldots \ldots \ldots$ & 1314 & 1 \\
\hline No. of infertile $\ldots \ldots \ldots \ldots \ldots \ldots$ & 334 & 74.6 fertility \\
\hline No of dead embryos $\left(\mathrm{D}_{1}\right)^{*} \ldots \ldots \ldots$ & $473^{*}$ & 48.3 of fertile eggs \\
\hline No. of dead embryos $\left\{\left(D_{2+3}\right) \ldots \ldots \ldots\right.$ & 70 & 7.1 of fertile eggs \\
\hline No. of chicks $\ldots \ldots \ldots \ldots \ldots \ldots \ldots$ & 437 & $\begin{array}{l}30.1 \text { of all eggs } \\
44.6 \text { of fertile eggs }\end{array}$ \\
\hline No. of male chicks $\ldots \ldots \ldots \ldots \ldots \ldots$ & 297 & 68.0 of all chicks or $2 \cdot 125: 1$ \\
\hline No. of female chicks ............ & 140 & 32.0 of all chicks \\
\hline
\end{tabular}

* This male was also heterozygous for the $O S U$ spontaneous chromosome translocation which explains the 48.3 p. 100 of early dead embryos.

\section{REPRODUCTION}

We can now report on reproduction in different types of matings. First, when dwarf females are produced by mating dwarf males with normal females, we indicated earlier this is how we produce the females needed in the nutrition studies. It is the easiest method to produce dwarf stock in a large breeding organization. Only a small number of males need to be bred to allow the production of a very large number of dwarf pullets. Results over a period of years are illustrated in table 3 .

The first year of this program in 1965 we did not have a sufficient number of males to mate in natural matings with the females available and necessary to produce the number of pullets required. We therefore resorted to artificial insemination. 
In I 966 the number of males was again insufficient but we decided to use the small number available in groups that we rotated from pen to pen every three days with a period of three days in each cycle of nine days without males. In I 967 we had enough

\section{TABLE 3}

Fertility and hatchability in matings of dwarf males with normal-size females

Taux de fertilité et d'éclosion dans des accouplements de mâles nains et de femelles de taille normale

\begin{tabular}{|c|c|c|c|c|c|c|c|c|c|}
\hline Year & 1965 & 1966 & 1967 & 1968 & 1969 & $1970 a$ & $1970 b$ & $1971 a$ & $1971 b$ \\
\hline No. pens & 12 & 6 & 16 & 9 & 6 & 9 & 9 & 6 & 6 \\
\hline Hens per pen & 50 & 50 & 50 & 50 & 145 & 80 & 80 & 80 & 80 \\
\hline Males per pen..... & A. $\mathbf{I}$. & $\begin{array}{c}\text { rotation } \\
5-0-3\end{array}$ & 3 & 5 & 4 & 8 & 8 & 8 & 8 \\
\hline Male : females & - & - & $\approx 1: 15$ & $\approx 1: 10$ & $\approx 1: 10$ & $\approx 1: 10$ & $\approx 1: 10$ & $\approx 1: 10$ & $\approx 1: 10$ \\
\hline No. of eggs .... & 2490 & 3027 & 2400 & 3541 & 3686 & 2426 & 4300 & 1258 & 4049 \\
\hline Fertility p. $100 \ldots$ & - & 80.5 & 80.8 & 84.8 & 41.9 & 75.1 & 88.7 & 93.4 & 97.8 \\
\hline \multicolumn{10}{|l|}{ Hatch p. 100: } \\
\hline All eggs......... & 81.3 & 70.2 & 75.5 & 74.0 & 38.7 & 70.0 & 75.0 & 79.7 & 82.9 \\
\hline Fertile eggs ..... & - & 87.2 & 93.4 & 87.3 & 92.4 & 93.2 & 84.5 & 85.3 & 84.8 \\
\hline
\end{tabular}

males to mate in the ratio of I : I5 but the fertility ( $80.8 \mathrm{p}$. I00) was not considered satisfactory. In I968 and since, the male-female ratio was lowered to I : Io but only this year in I97I has fertility reached a high level and rapidly enough to be considered satisfactory. What may be a simple explanation for this improvement is that until this year the males, kept in the dark to reduce fighting, were moved directly from dark holding pens to the breeding pens. Apparently it took a period of time for them to produce satisfactory amounts of semen, to adjust to their new surroundings and to mate with all the females. This year we moved the males from darkness to a lighted pen approximately one month before they were to be placed with the hens. We have plotted the rate of increase in fertility in the different years in the different pens and the results are illustrated in fig. $3 a-3 e$.

TABLE 4

Fertility and hatchability in dwarf and in normal matings

Taux de fertilité et d'éclosion dans les accouplements de nains ou de normaux

\begin{tabular}{|c|c|c|c|c|c|c|c|c|c|c|}
\hline \multirow{2}{*}{ Type } & \multicolumn{2}{|c|}{1966} & \multicolumn{2}{|c|}{1967} & \multicolumn{2}{|c|}{1968} & \multicolumn{2}{|c|}{1969} & \multicolumn{2}{|c|}{1970} \\
\hline & Normal & Dwarf & Normal & Dwarf & Normal & Dwarf & Normal & Dwarf & Normal & Dwarf \\
\hline $\begin{array}{l}\text { Mating } \ldots \ldots \\
\text { Eggs } \ldots . . . \\
\% \text { fertility } \ldots \\
\% \text { hatch FE. }\end{array}$ & $\begin{array}{c}\text { Natural } \\
1783 \\
84.3 \\
84.9\end{array}$ & $\begin{array}{c}\text { A. I. } \\
1553 \\
87.6 \\
89.0\end{array}$ & $\begin{array}{c}\text { Natural } \\
1784 \\
92.0 \\
88\end{array}$ & $\begin{array}{c}\text { A. I. } \\
1101 \\
91.3 \\
88.3\end{array}$ & $\begin{array}{c}\text { Natural } \\
1649 \\
92.5 \\
77.8\end{array}$ & $\begin{array}{c}\text { A. I. } \\
1360 \\
94.0 \\
91.1\end{array}$ & $\begin{array}{c}\text { Natural } \\
2538 \\
67.7 \\
87.0\end{array}$ & $\begin{array}{c}\text { A. I. } \\
1601 \\
95.4 \\
86.3\end{array}$ & $\begin{array}{l}\text { A. I. } \\
2244 \\
84.7 \\
82.9\end{array}$ & $\begin{array}{c}\text { A. I. } \\
1639 \\
89.3 \\
85.0\end{array}$ \\
\hline
\end{tabular}




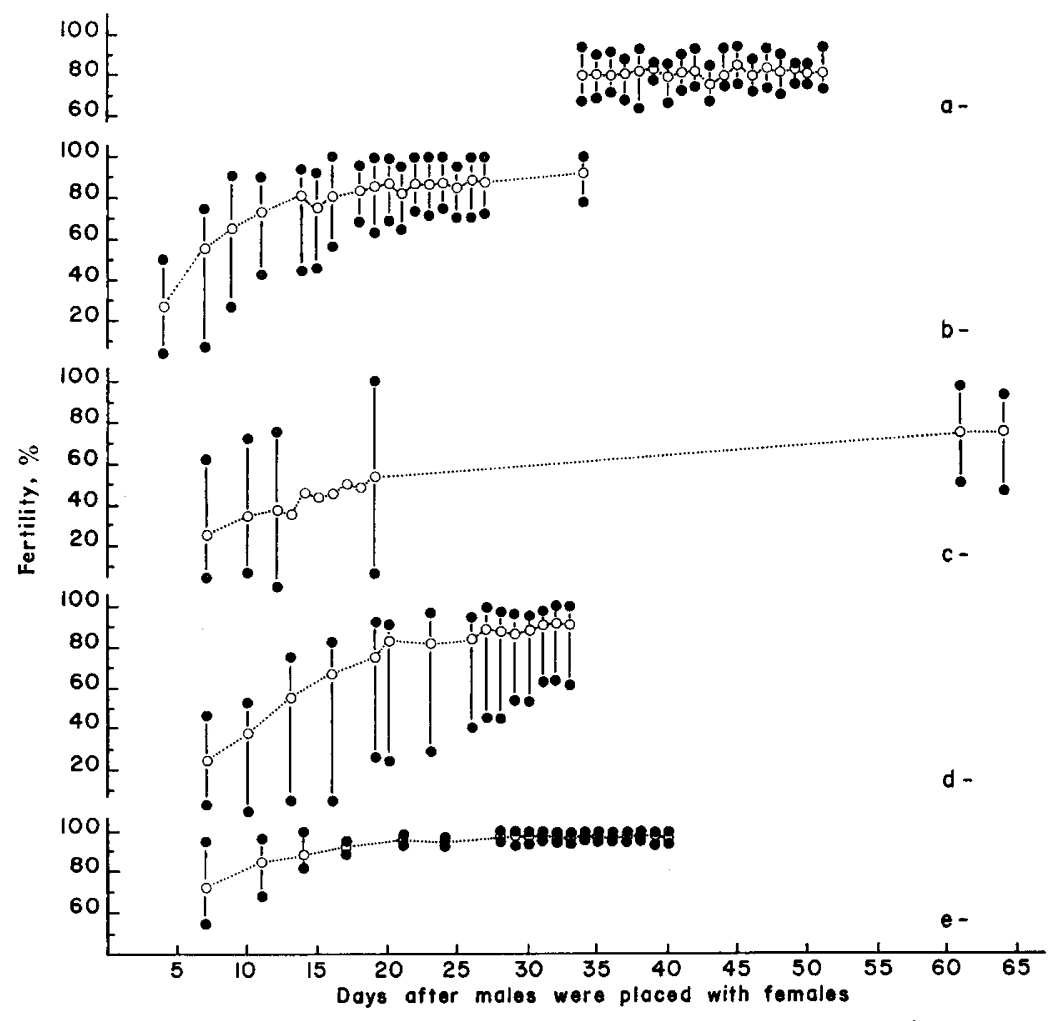

FIG. 3. - Onset and level of fertility in natural matings of dwarf males with normal-size hens

The averages are represented by $O$ and the range by

a) 6 pens of 50 females. Groups of 5 and 3 males rotated every three days with a period of three days without males (I 966 ).

b) 9 pens of 50 females. 5 males per pen or $\square$ I : ro (I968).

c) 6 pens of 45 females. 4 males per pen or $\square$ I : ro (I969).

d) 9 pens of 80 females. 8 males per pen or $\square$ I : Io (I97o).

e) 6 pens of 80 females. 8 males per pen or $\square$ I : ro (I97I).

Établissement et niveau de la fertilité

dans les accouplements naturels de mâles nains avec des poules de taille normale

Les moyennes sont représentées par o et les intervalles de variation par •

a) 6 parquets de 50 femelles. Groupes de 5 et 3 mâles en rotation tous les trois jours avec une période de trois jours sans mâles (1966).

b) 9 parquets de 50 femelles. 5 mâles par parquet ou $\square$ r/ro (rg68),

c) 6 parquets de 45 femelles. 4 mâles par parquet ou $\square$ I/ro (1969).

d) 9 parquets de 80 femelles. 8 mâles par parquet ou $\square$ r/ro (r970).

e) 6 parquets de 80 femelles. 8 mâles par parquet ou $\square$ I/Io (I97r).

As indicated earlier we are now satisfied that good fertility can be obtained in matings of dwarf males and normal females but we would like to increase, if possible, the I : ro male-female ratio we have used in recent years. We have no explanation for the low fertility observed in 1969 not only in these dwarf-normal matings but also in our regular matings as we note in Table 4 other than some lighting problem which one cannot identify more completely.

Second, dwarf birds can of course be reproduced as a line which we can submit 
to selection for economic traits. Table 4 shows the fertility and hatchability observed in recent years in our selection program in the dwarf and in the normal size lines for comparative purposes. It is evident that the reproductive performance of our dwarf line is comparable to that of our normal size Production Line.

\section{GENETIC SELECTION}

Observations on our dwarf layers in the first few years revealed that their principal defects were delayed sexual maturity, smaller eggs and lower egg production. Limited facilities did not allow us to test as many families as would have been desirable, so we compromised. We raised more dwarf pullets than we had room to test for the entire production period and we placed heavy selection pressure on sexual maturity and on initial egg size. We rigorously culled individuals and families that matured late and that laid small eggs. Although a convenient compromise it unfortunately prevented us from obtaining comparative performance data in the early years except in the nutrition investigations. In more recent years we have been able to

TABLE 5

Hen-housed performance of normal and dwarf layers at 40 weeks of age

Performances rapportées aux poules logées pour des pondeuses normales et naines à 40 semaines d'âge

\begin{tabular}{|c|c|c|c|c|c|c|c|c|}
\hline \multirow{3}{*}{ Year } & \multirow{3}{*}{ Type } & \multirow{3}{*}{ Number } & \multirow{3}{*}{$\begin{array}{c}\text { S. M. } \\
\text { wks }\end{array}$} & \multirow{3}{*}{$\begin{array}{c}\text { H. H. } \\
\text { eggs }\end{array}$} & \multicolumn{2}{|c|}{ Body weight } & \multirow{3}{*}{$\begin{array}{l}\text { Egg wt. } \\
\text { Dec. (g) }\end{array}$} & \multirow{3}{*}{$\begin{array}{c}\text { Livability } \\
(\%)\end{array}$} \\
\hline & & & & & 10 wks & 20 wks & & \\
\hline & & & & & \multicolumn{2}{|c|}{ (lbs) } & & \\
\hline $1970-71 *$ & $\begin{array}{l}D w \ldots \ldots \ldots \\
d w \ldots \ldots \ldots \ldots \\
d w / D w(100)\end{array}$ & $\begin{array}{l}628 \\
819\end{array}$ & $\begin{array}{r}22.6 \\
24.3 \\
107.5\end{array}$ & $\begin{array}{r}102.2 \\
85.2 \\
83.4\end{array}$ & $\begin{array}{r}1.8 \\
1.4 \\
77.8\end{array}$ & $\begin{array}{r}3.1 \\
2.3 \\
74.2\end{array}$ & $\begin{array}{l}58.7 \\
55.7 \\
94.9\end{array}$ & $\begin{array}{l}96.7 \\
94.3 \\
97.5\end{array}$ \\
\hline $1969-70^{*}$ & $\begin{array}{l}D w \ldots \ldots \ldots \\
d w \ldots \ldots \ldots \\
d w / D w(100)\end{array}$ & $\begin{array}{l}644 \\
582\end{array}$ & $\begin{array}{r}24.2 \\
25.9 \\
107.0\end{array}$ & $\begin{array}{l}88.7 \\
72.4 \\
81.6\end{array}$ & $\begin{array}{r}1.5 \\
1.2 \\
80.0\end{array}$ & $\begin{array}{r}3.4 \\
2.4 \\
70.6\end{array}$ & $\begin{array}{l}57.6 \\
55.1 \\
95.7\end{array}$ & $\begin{array}{l}97.2 \\
96.2 \\
99.0\end{array}$ \\
\hline $1968-69^{*}$ & $\begin{array}{l}D w \ldots \ldots \ldots \\
d w \ldots \ldots \ldots \\
d w / D w(100)\end{array}$ & $\begin{array}{l}489 \\
494\end{array}$ & $\begin{array}{r}25.0 \\
27.7 \\
110.8\end{array}$ & $\begin{array}{l}74.3 \\
51.3 \\
69.0\end{array}$ & $\begin{array}{r}1.7 \\
1.2 \\
70.6\end{array}$ & $\begin{array}{l}3.1 \\
-\end{array}$ & $\begin{array}{l}53.9 \\
51.1 \\
94.8\end{array}$ & $\begin{array}{r}91.0 \\
95.3 \\
104.7\end{array}$ \\
\hline $1967-68^{* *}$ & $\begin{array}{l}\begin{array}{l}D w \\
d w\end{array} \ldots \ldots \ldots \\
d w / D w(100)\end{array}$ & $\begin{array}{l}449 \\
382\end{array}$ & $\begin{array}{r}21.9 \\
28.7 \\
131.0\end{array}$ & $\begin{array}{l}43.0 \\
23.4 \\
54.4\end{array}$ & $\begin{array}{r}1.8 \\
1.3 \\
72.2\end{array}$ & $\begin{array}{l}2.8 \\
-\end{array}$ & $\begin{array}{l}57.0 \\
53.8 \\
94.4\end{array}$ & $\begin{array}{r}95.3 \\
98.4 \\
103.3\end{array}$ \\
\hline $1966 \cdot 67 * *$ & $\begin{array}{l}D w \ldots \ldots \ldots \\
d w \ldots \ldots \ldots \ldots \\
d w / D w(100)\end{array}$ & $\begin{array}{l}458 \\
400\end{array}$ & $\begin{array}{r}21.5 \\
32.5 \\
151.1\end{array}$ & $\begin{array}{l}46.2 \\
10.6 \\
22.9\end{array}$ & $\begin{array}{r}1.9 \\
1.3 \\
68.4\end{array}$ & $\begin{array}{r}3.0 \\
2.1 \\
70.0\end{array}$ & $\begin{array}{l}55.7 \\
52.3 \\
93.9\end{array}$ & $\begin{array}{l}97.2 \\
95.5 \\
98.3\end{array}$ \\
\hline $1965-66^{* *}$ & $\begin{array}{l}D w \ldots \ldots \ldots \\
d w \ldots \ldots \ldots \\
d w / D w(100)\end{array}$ & $\begin{array}{l}519 \\
240\end{array}$ & $\begin{array}{r}22.2 \\
27.9 \\
125.6\end{array}$ & $\begin{array}{l}46.1 \\
20.0 \\
43.4\end{array}$ & $\begin{array}{r}1.7 \\
1.4 \\
82.4\end{array}$ & $\begin{array}{l}2.9 \\
-\end{array}$ & $\begin{array}{l}56.1 \\
53.2 \\
94.8\end{array}$ & $\begin{array}{l}95.8 \\
91.7 \\
95.7\end{array}$ \\
\hline
\end{tabular}

* Full trapnesting.

** 3-day a week trapnesting. 
allocate more cage space to the dwarf selection program and we can report on the relative performance of the dwarf line and of our OSU Production Line. Table 5 gives those comparative data for recent years.

Sexual maturity (SM) expressed in weeks was as high as 32.5 weeks in the dwarf line in I966-67 but it has gradually decreased to 24.3 weeks in the current generation which is only I.7 weeks later than that of our OSU Production Line.

Hen-housed egg production $(\mathrm{HH})$ which was disappointingly low in $1965-66$, I966-67, and I968-69, began to show improvement in I968-69 and in the current generation it is $83.4 \mathrm{p}$. IOo as high as that observed in the OSU Production Line. We should perhaps indicate that the dwarf layers in this selection project are fed a commercial complete breeder I5 p. Ioo protein ration which we have shown in our nutrition investigations to be inadequate in protein or methionine for them. This inadequacy provides an additional stress factor which hopefully increases the sensitivity of our selection.

Body weight as measured at Io and at 20 weeks of age, when the layers are housed, has not changed in the dwarf layers but only because of the restriction placed on it in our selection. It would very likely have increased as a result of a correlated response to our selection for egg size. We have not always been able to measure body weight of all the dwarf layers at 20 weeks because of the limited housing facilities in prior years.

Egg size, as we have indicated earlier, is critical for dwarf layers and we have placed emphasis on this trait in our selection. We are making progress and the fact, as demonstrated by FESTING and NoRDSKOG (I967), that egg size can be manipulated somewhat independently of body weight and which is so well demonstrated historically in the modern Leghorn is certainly justification for optimism.

Livability in the dwarf line has usually been superior to that observed in our OSU Production Line.

\section{NUTRITION STUDIES}

Our nutrition studies began in 1958 with the association of GHA with the research project. That first year we placed I 20 dwarf and 120 of their normal size sisters in individual cages. We kept individual records of feed consumption, of all eggs produced and of their weight. We compared the effects of two calcium-phosphorus levels (3.0 p. I00 Ca-0.9 p. IOo P and 2.25 p. Ioo Ca-o.6 p. Ioo P) on corn-soybean mealfish meal rations, with similar calorie protein ratios $(84.9-87 . \mathrm{I})$, containing $\mathrm{I} 5 \mathrm{p}$. Ioo protein with either the normal or double that level of a vitamin trace mineral supplement (DVTMS) and I 8 p. Ioo protein with double the normal vitamin trace mineral supplementation. These results were reported by ARSCOT' $\mathrm{r}$, RACHAPAETAYAKOM and BERNIER (I96I) and are summarized in table 6. The additional calcium and phosphorus improved egg production and shell quality of dwarf layers more than those of their normal sisters. The additional vitamin trace mineral supplementation also benefited egg production and shell quality in the dwarf layers. The $\mathrm{r} 8 \mathrm{p}$. Ioo protein level did not bring an improvement in egg production but it resulted in a marked decrease in feed intake which may have masked the possible improvement in egg production. Egg weight was not affected by any of the treatments. 


\section{TABLE 6}

Observations on gross requirements for certain nutrients in dwarf White Leghorn hens

Arscott, Rachapaetayakom and Bernier (I96i)

Observations sur les besoins globaux en certains nutriments pour des poules Leghorn blanches naines

Arscott, Rachapaetayakom et Bernier (I96I)

\begin{tabular}{|c|c|c|c|c|c|c|}
\hline $\begin{array}{c}\text { Type } \\
\text { of layers }\end{array}$ & Treatment & $\begin{array}{l}\text { Body wt. } \\
\text { (lb) }\end{array}$ & Eggs (bs.) & $\begin{array}{l}\text { Feed consumed } \\
\text { (lb/bird) }\end{array}$ & $\begin{array}{l}\text { Egg wt. } \\
\text { (g) }\end{array}$ & $\begin{array}{l}\text { Spec. gravity } \\
\times 10^{3}-1000\end{array}$ \\
\hline \multirow{2}{*}{ Normal } & $\mathrm{Ca} \% \quad \mathrm{P} \%$ & & & & & \\
\hline & $\begin{array}{ll}2.25 & 0.6 \\
3.00 & 0.9\end{array}$ & $\begin{array}{l}4.51 \\
4.55\end{array}$ & $\begin{array}{l}13.7 \\
14.4\end{array}$ & $\begin{array}{l}6.15 \\
640\end{array}$ & $\begin{array}{l}60.5 \\
610\end{array}$ & 78.7 \\
\hline \multirow{2}{*}{ Dwarf } & 2.25 & 2.89 & 11.2 & 3.97 & 53.9 & 73.8 \\
\hline & $\begin{array}{ll}3.00 & 0.9\end{array}$ & 2.95 & 12.9 & 4.30 & 54.6 & 77.0 \\
\hline Normal & $\begin{array}{c}15 \% \text { protein } \\
+ \text { DVTMS } \\
18 \% \text { protein }\end{array}$ & $\begin{array}{l}4.66 \\
4.49\end{array}$ & $\begin{array}{l}14.4 \\
14.2\end{array}$ & $\begin{array}{l}6.58 \\
6.73\end{array}$ & $\begin{array}{l}61.2 \\
61.0\end{array}$ & $\begin{array}{l}79.2 \\
80.4\end{array}$ \\
\hline \multirow{4}{*}{ Dwarf } & + DVTMS & 4.62 & 13.6 & 5.53 & 60.5 & 79.0 \\
\hline & $15 \%$ protein & 2.88 & 11.7 & 4.22 & 54.6 & 75.0 \\
\hline & $\begin{array}{l}+ \text { DVTMS } \\
18 \% \text { protein }\end{array}$ & 2.95 & 12.3 & 4.47 & 54.3 & 76.8 \\
\hline & + DVTMS & 2.94 & 12.2 & 3.70 & 53.9 & 74.5 \\
\hline
\end{tabular}

TABLE 7

Influence of ascorbic acid, calcium and phosphorus on performance of normal size and dwarf White Leghorn hens

Arscott, Rachapaetayakom, Bernier and Adams (1962)

Influence de l'acide ascorbique, du calcium et du phosphore sur les performances de poules Leghorn blanches de taille normale ou naines

Arscott, Rachapaetayakom, Bernier and Adams (i962)

\begin{tabular}{|c|c|c|c|c|c|c|c|c|}
\hline \multirow{3}{*}{$\begin{array}{c}\text { Type } \\
\text { of layer }\end{array}$} & \multicolumn{3}{|c|}{ Treatment } & \multirow{3}{*}{$\begin{array}{c}\text { Egg spec. } \\
\text { gravity }\end{array}$} & \multicolumn{2}{|c|}{ Blood } & \multirow{3}{*}{$\begin{array}{l}\text { Egg prod. } \\
(\%)\end{array}$} & \multirow{3}{*}{$\begin{array}{c}\text { Egg wt. } \\
\text { (g) }\end{array}$} \\
\hline & $\mathrm{Ca} \%$ & $\mathbf{P} \%$ & Vit. C & & $\mathrm{Ca}$ & $\mathbf{P}$ & & \\
\hline & & & $\left.(1)_{5} / 10\right)$ & & \multicolumn{2}{|c|}{$(\mathrm{mg} \%)$} & & \\
\hline \multirow{4}{*}{ Normal } & 2.25 & 0.6 & 0 & 1.0757 & 28.7 & 4.6 & 60.5 & 59 \\
\hline & 2.25 & 0.6 & 10 & 1.0767 & 27.6 & 4.4 & 66.9 & 58 \\
\hline & 3.00 & 0.6 & 0 & $1.0781 *$ & $30.5 *$ & $4.9 *$ & 69.7 & 59 \\
\hline & 2.25 & 0.9 & 0 & $1.0743^{*}$ & 28.2 & $5.4^{*}$ & 73.6 & 59 \\
\hline \multirow{3}{*}{ Dwarf } & 2.25 & 0.6 & 0 & 1.0684 & 一 & - & 37.1 & 57 \\
\hline & 2.25 & 0.6 & 10 & 1.0689 & - & - & 33.8 & 58 \\
\hline & 3.00 & 0.6 & 0 & $1.0734 *$ & - & - & 41.4 & 58 \\
\hline
\end{tabular}

* Significantly different from control $\mathrm{P}<.05$. 
Our next two experiments conducted in I96I and I962 compared different levels of calcium and have not been reported as yet. In general they confirm the results obtained in the first experiment showing improved shell quality from higher calcium levels.

In our third investigation we studied the influence of ascorbic acid, calcium and phosphorus on egg shell quality as measured by specific gravity. This experiment was reported by ARscotit, Rachapaetayakom, Bernier and Adams (I962) and the

TABLE 8

Growth and feed requirements of dwarf White Leghorn pullets compared to their normal-size sisters

Body weights (g)

Bernier and Arscott (i966)

Croissance et besoins alimentaives de poulettes Leghorn blanches naines comparées à leurs sours de taille normale

Poids corporels (g)

Bernier et Arscott (r966)

\begin{tabular}{|c|c|c|c|c|c|}
\hline \multirow{2}{*}{ Type } & \multicolumn{5}{|c|}{ Weeks } \\
\hline & 4 & 8 & 12 & 17 & 23 \\
\hline Normal......... & 289 & 641 & 1006 & 1224 & 1464 \\
\hline Dwarf . & 218 & 460 & 706 & 896 & 1029 \\
\hline$\frac{\text { Dwarf }}{T} \times$ & 75.4 & 71.8 & 70.2 & 73.2 & 70.3 \\
\hline$\overline{\text { Normal }}$ & 70.4 & 11.0 & 10.2 & 10.2 & 10.0 \\
\hline
\end{tabular}

TABLE 9

Growth and feed requirements of dwarf White Leghorn pullets compared to their normal-size sisters

Feed consumption (g)

Bernier and ARscott (1966)

Croissance et besoins alimentaires de poulettes Leghorn blanches naines comparés à leurs sceurs de taille normale

Consommation alimentaire $(\mathrm{g})$

Bernier et Arscott (I966)

\begin{tabular}{|c|c|c|c|c|c|}
\hline \multirow{2}{*}{ Type } & \multicolumn{5}{|c|}{ Weeks } \\
\hline & 4 & 8 & 12 & 17 & 23 \\
\hline Normal. ........... & 499 & 1669 & 3280 & 5670 & 8634 \\
\hline Dwarf $\ldots \ldots \ldots \ldots$ & 365 & 1168 & 2221 & 3949 & 5838 \\
\hline$\frac{\text { Dwarf }}{\text { Normal }} \times 100$. & 73.1 & 70.0 & 67.7 & 69.6 & 67.6 \\
\hline
\end{tabular}


results are illustrated in table 7. No improvement in egg shell thickness was apparent with either normal size or dwarf White Leghorn fed rations containing ascorbic acid. A marked improvement in shell thickness, accompanied by an increase in blood calcium and phosphorus, was obtained in normal size birds in the presence of $3 \mathrm{p}$. Ioo calcium and a similar improvement in shell thickness was obtained with the dwarfs fed the rations containing $3 \mathrm{p}$. Ioo calcium. Increasing the phosphorus level to 0.9 p. Ioo appeared to reduce shell thickness and to increase blood phosphorus. This latter observation has since been reported by others.

TABLE IO

Growth and feed requirements of dwarf White Leghorn pullets compared to their normal-size sisters

Feed conversion

Bernier and Arscott (1966)

Croissance et besoins alimentaires de poulettes Leghorn blanches naines comparées à leurs saurs de taille normale

Indice de conversion

Bernier et Arscott (I966)

\begin{tabular}{|c|c|c|c|c|c|}
\hline \multirow{2}{*}{ Type } & \multicolumn{5}{|c|}{ Weeks } \\
\hline & 4 & 8 & 12 & 17 & 23 \\
\hline Normal............ & 1.73 & 2.61 & 3.26 & 4.63 & 5.90 \\
\hline Dwarf ... & 1.67 & 2.54 & 3.14 & 4.41 & 5.68 \\
\hline
\end{tabular}

TABLE II

Growth and feed requirements of dwarf White Leghorn pullets compared to their normal-size sisters

Cumulative mortality $(\%)$

BERnier and ArscotT (I966)

Croissance et besoins alimentaires de poulettes Leghorn blanches naines comparées à leurs sours de taille normale

Mortalité cumulée (\%)

BERNIER et Arscotr (I966)

\begin{tabular}{|c|c|c|c|c|}
\hline \multirow{2}{*}{ Type $\left({ }^{1}\right)$} & \multicolumn{4}{|c|}{ Weeks } \\
\hline & 4 & 8 & 12 & 17 \\
\hline Normal.......... & 1.7 & 4.4 & 8.4 & 10.9 \\
\hline Dwarf $\ldots . . \ldots \ldots$ & 6.6 & 7.1 & 9.0 & 9.7 \\
\hline
\end{tabular}

( $\left.{ }^{1}\right) 700$ chicks of each type at start. 
In our fourth nutrition investigation we measured the growth and feed requirements of developing dwarf pullets compared to their normal size sisters. We used two populations of 700 day old chicks of each type which were each brooded in duplicate groups. Both types of birds were fed the same rations. During the first 8 weeks they were fed a high energy corn-soybean meal-5 p. Ioo fish meal starter diet with $20 \mathrm{p}$. Ioo protein and I $370 \mathrm{kcal}$. metabolizable energy/lb. From the eighth through the 23rd week the birds were fed a medium energy corn-barley-soybean meal-2 p. Ioo fish meal grower diet with $\mathrm{I} 4.9 \mathrm{p}$. Ioo protein and I $285 \mathrm{kcal}$. metabolizable energy/lb. Body weight and feed consumption were recorded at 4-6 week intervals. The results were reported by BERNIER and ARSCOTT (I966) and are illustrated in Tables 8 and 9 and fig. $4 a-4 b$ for both body weight and feed consumption. Feed conversion as shown in table Io consistently favored the dwarf pullets. Mortality, Table II, was heavier in the first 8 weeks of life in the dwarfs possibly because they were not rigidly culled at hatching time because of limited numbers. Table I2 illustrates the fact that even after allowing for the delayed sexual maturity of the dwarf pullets they still required much less feed to reach laying age.

TABLE I2

Growth and feed requirements of dwarf White Leghorn pullets compared to their normal-size sisters

Data recalculated for time required to reach $25 \mathrm{p}$. 100 egg production Bernier and Arscott (1966),

Croissance et besoins alimentaires de poulettes Leghorn blanches naines comparées à leurs scurs de taille normale

Données recalculées d'après le temps requis pour atteindre $25 \mathrm{p}$. roo de ponte BERNIER et ARscott (I966)

\begin{tabular}{l|c|c}
\hline \hline & $\begin{array}{c}\text { Body wts. } \\
(\mathrm{g})\end{array}$ & $\begin{array}{c}\text { Feed Cons. } \\
(\mathrm{g})\end{array}$ \\
\hline Normal $: 23$ wks. $\ldots \ldots \ldots$ & 1464 \\
Dwarf $: 25$ wks $\ldots \ldots \ldots \ldots$ & 1094 & 8634 \\
\hline Dwarf & 6302 \\
\hline Normal & 74.7 & 73.0 \\
\hline
\end{tabular}

Our fifth investigation involved two experiments comparing the development and feed requirements of developing dwarf pullets fed a 20 p. Ioo protein starter for the first four or the first eight weeks followed in both instances by a $15 \mathrm{p}$. IOo protein developer. The results have not been published as yet but they are satisfactory and furthermore the egg production of the pullets is not impaired by the lower protein level fed during the development period.

The sixth investigation compared different protein levels in two separate 280day periods using corn-soybean meal base diets for the dwarf layers, supplemented by higher calcium and vitamin trace mineral levels than those fed the normal layers3.7 p. IOO vs. 2.8 p. IOO $\mathrm{Ca}$ and 0.33 p. I0O vs. 0.25 p. IOO vitamin trace mineral 
supplement respectively. The protein levels ranged from I 2 to $2 \mathrm{I}$ p. roo for the dwarf layers and from $\mathrm{I} 2$ to $\mathrm{I} 8 \mathrm{p}$. Ioo for their normal sisters. The results of these two experiments have been reported by ARSCOTT and BERNIER (I968) and BERNIER and ARscoTt (I968) and are shown in Tables I3-I6. Egg production and feed per dozen
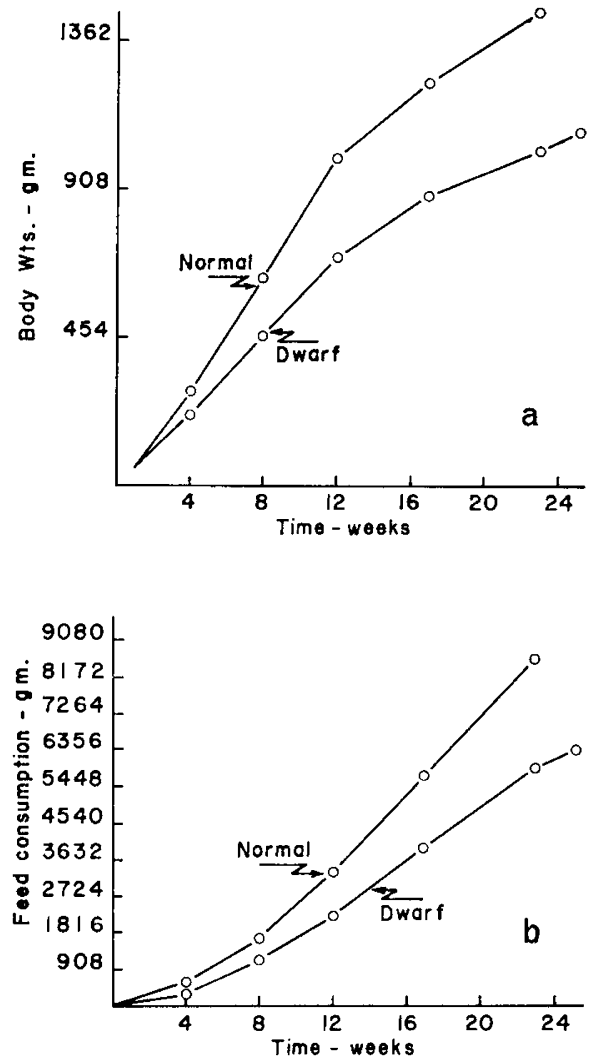

Fi: 4. - Growth and feed requirements of dwarf White Leghorn pullets compared to their normal-size sisters

(Bernier and Arscott, I966)

a) Body weight.

b) Feed consumption.

Croissance et besoins nutritionnels

de poulettes Leghorn blanches naines comparées à leurs saurs de taille normale

(Bernier et Arscott, I966)

a) Poids corporels.

b) Consommation alimentaire.

eggs for the dwarfs both plateaued at the I5 p. Ioo level of protein while in normals this occurred at $\mathrm{r}_{4} \mathrm{p}$. IOO. The dwarfs laid I3 p. Ioo fewer eggs but the feed required per dozen eggs was $\mathrm{I} 8 \mathrm{p}$. Ioo less than in normals. Egg size increased with protein levels to $2 \mathrm{I}$ p. Ioo in dwarfs but in normals it plateaued at $\mathrm{I} 6 \mathrm{p}$. Ioo protein. Feed consumption of dwarfs increased with protein levels in Experiment $\mathrm{I}$ but it plateaued at $I 5$ p. Ioo in Experiment 2. Dwarfs fed $2 \mathrm{I}$ p. Ioo protein had a protein intake of 
I7.3 grams while normals nad a protein intake of 17.2 grams when fed I6 p. Ioo protein. The addition of $.05 \mathrm{p}$. Ioo d1-methionine to the I2 p. IOo protein diet of dwarfs increased egg weight significantly but $.05 \mathrm{p}$. Ioo lysine was without effect.

\section{TABLE I3}

\section{Effect of protein level on egg production}

Av. ten 28-day periods

Arscott and Bernier (r968)

Bernier and Arscott (r968)

Effet du taux protéique sur la production d'ceufs

Moyenne de dix périodes de 28 jours

\begin{tabular}{|c|c|c|}
\hline \multirow{2}{*}{ Prot. level $(\%)$} & \multicolumn{2}{|c|}{ Egg prod. (\%) (hen day) } \\
\hline & Exp't 1 & Exp't 2 \\
\hline \multicolumn{3}{|c|}{ Dwarf } \\
\hline $\begin{array}{l}12+\text { meth }+(\text { lys }) \\
14 \\
15 \\
16 \\
18 \\
21\end{array}$ & $\begin{array}{l}41.0^{a}+42.8^{a} \\
48.5^{b} \\
- \\
56.7^{c} \\
60.0^{c} \\
-\end{array}$ & $\begin{array}{l}\frac{49.8^{a}}{}+\left(51.9^{a}\right) \\
\overline{60.2^{b}} \\
\overline{59.9^{b}} \\
60.8^{b}\end{array}$ \\
\hline \multicolumn{3}{|c|}{ Normal } \\
\hline $\begin{array}{l}12 \\
14 \\
16 \\
18\end{array}$ & $\begin{array}{l}60.8^{c d} \\
68.5^{e *} \\
65.9^{e *} \\
69.3^{e *}\end{array}$ & $\begin{array}{l}- \\
69.2^{c} \\
-\end{array}$ \\
\hline
\end{tabular}

1. Different letters within exp'ts indicate sig. differences $(p<.01)$.

$*(p<.05)$.

Our last reported nutrition investigation also involved two experiments each of ten 28-day periods and in which a ration of $15.2 \mathrm{p}$. Ioo protein, with and without different levels (.025, .05, .I p. IOo) of dl-methionine, a level (.05 p. I00) of lysine and a level ( 2 p. IOo) of safflower oil, alone and in combination, as well as a ration containing $20.9 \mathrm{p}$. roo protein, were fed to duplicate lots of dwarf layers and compared to a ration of $I_{5} .8 \mathrm{p}$. Ioo protein fed to duplicate lots of normals. This study.was reported by ARSCOTT and BERNIER (I970) and table I7 shows that in Experiment I only the higher protein level resulted in a significant improvement in egg production of the dwarfs although .05 p. Ioo dl-methionine resulted in an intermediate response. In Experiment 2 no difference was observed between the two protein levels or the various levels of methionine or combinations of methionine (.05 p. I0o), lysine and safflower oil. There was a tendency towards higher production in the presence: of $.05 \mathrm{p}$. Ioo methionine or $20.9 \mathrm{p}$. Ioo protein. 
Table I 8 shows that in Experiment I the addition of .05 p. Ioo d1-methionine and the 20.9 p. Ioo protein rations both brought about a significant increase in egg weight. In Experiment 2 increasing levels of methionine resulted in increased egg weight but only the .I p. Ioo level of methionine showed a significant improvement over the negative control. The dwarf group fed the $20.9 \mathrm{p}$. Ioo protein diet also laid significantly larger eggs than the control group. Combinations involving .05 p. Ioo

TABLE I4

Effect of protein level on egg weight

Av. ten 28-day periods

ARscott and Bernier (I968)

Bernier and Arscott (1968)

Effet du taux protéique sur le poids de l'cuf

Moyenne de dix périodes de 28 jours

\begin{tabular}{|c|c|c|}
\hline \multirow{2}{*}{ Prot. level $(\%)$} & \multicolumn{2}{|c|}{ Egg wt. (g) } \\
\hline & Exp't 1 & Exp't 2 \\
\hline \multicolumn{3}{|c|}{ Dwarf } \\
\hline $\begin{array}{l}12+\text { meth }+ \text { (lys) } \\
14 \\
15 \\
16 \\
18 \\
21\end{array}$ & $\begin{array}{l}48.2^{a}+51.1^{b c} \\
50.1^{b} \\
- \\
51.6^{c} \\
53.5^{d} \\
-\end{array}$ & $\begin{array}{l}50.9^{a}+\left(51.7^{a b}\right) \\
- \\
52.7^{b c} \\
- \\
54.0^{c} \\
55.7^{d}\end{array}$ \\
\hline \multicolumn{3}{|c|}{ Normal } \\
\hline $\begin{array}{l}12 \\
14 \\
16 \\
18\end{array}$ & $\begin{array}{l}56.8^{e} \\
57.0^{e f} \\
58.1^{f} * \\
58.2^{f *}\end{array}$ & $\begin{array}{l}- \\
58.0^{e} \\
-\end{array}$ \\
\hline
\end{tabular}

1. Different letters within exp'ts indicate sig. differences $(p<.01)$.

$*(p<.05)$.

dl-methionine and 2 p. Ioo safflower oil with or without .05 p. Ioo 1-1ysine also brought about a significant improvement in egg weight.

Table I9 shows the effect of protein level and supplements on feed per dozen eggs. The normals produced eggs less efficiently than the dwarfs. The most efficient performance was that of dwarfs fed the supplement of .05 p. Ioo d1-methionine in Experiment 2. The various treatments had no significant effect on final body weight of dwarfs. Normals weighed significantly more than dwarfs or 3.9 pounds as compared to 3.0 pounds.

It thus seems that supplementation of a I5.2 p. Ioo protein diet with .05 and .I dl-methionine improved egg production and egg weight in dwarfs to levels comparable to those observed with the 20.9 p. Ioo protein diet. However, dwarfs still 


\section{TABLE I5}

Calculated daily protein intake in relation to dietary protein level

Arscott and Bernier (1968)

Bernier and Arscott (1968)

Ingestion journalière de protéines calculée en relation avec le taux protéique de la ration

\begin{tabular}{|c|c|c|}
\hline \multirow{2}{*}{ Prot. level (\%) } & \multicolumn{2}{|c|}{ Daily prot. intake * $(\mathrm{g})$} \\
\hline & Exp't 1 & Exp't 2 \\
\hline \multicolumn{3}{|c|}{ Dwarf } \\
\hline $\begin{array}{l}12+\text { meth }+(l y s) \\
14 \\
15 \\
16 \\
18 \\
21\end{array}$ & $\begin{array}{l}8.0+8.4 \\
10.2 \\
- \\
12.2 \\
14.5 \\
-\end{array}$ & $\begin{array}{l}\frac{9.0}{-}+(9.4) \\
\frac{12.1}{-} \\
\overline{14.5} \\
17.3\end{array}$ \\
\hline \multicolumn{3}{|c|}{ Normal } \\
\hline $\begin{array}{l}12 \\
14 \\
16 \\
18\end{array}$ & $\begin{array}{l}14.3 \\
16.2 \\
18.3 \\
20.4\end{array}$ & $\frac{\overline{-}}{\overline{17.2}}$ \\
\hline
\end{tabular}

* Based on calculated prot. content to nearest tenth.

TABLE I6

Effect of protein level on feed per dozen eggs

Av. ten 28-day periods

ARscott and Bernier (I968)

BERnier and ARSCOTT (I968)

Effet du taux protéique sur la consommation par douzaine d'oufs pondus moyenne de dix périodes de 28 jours

\begin{tabular}{|c|c|c|}
\hline \multirow{2}{*}{ Prot. level $(\%)$} & \multicolumn{2}{|c|}{ Feed/doz eggs (lb) } \\
\hline & Exp't 1 & Exp't 2 \\
\hline \multicolumn{3}{|c|}{ Dwarf } \\
\hline $\begin{array}{l}12+\text { meth }+ \text { lys } \\
14 \\
15 \\
16 \\
18 \\
21\end{array}$ & $\begin{array}{l}4.52^{a}+4.43^{a b} \\
4.03^{b} \\
- \\
3.68^{c} \\
3.66^{c} \\
-\end{array}$ & $\begin{array}{l}3.9^{a}+\left(3.92^{a}\right) \\
- \\
3.51^{b} \\
- \\
3.55^{b} \\
3.63^{b}\end{array}$ \\
\hline \multicolumn{3}{|c|}{ Normal } \\
\hline $\begin{array}{l}12 \\
14 \\
16 \\
18\end{array}$ & $\begin{array}{l}5.11^{d} \\
4.54^{a} \\
4.69^{a d} \\
4.44^{a b}\end{array}$ & $\overline{\overline{4.24^{c}}}$ \\
\hline
\end{tabular}

(1) Different letters within exp'ts indicate sig. differences $(p<.01)$. 
laid fewer and smaller eggs than their normal size sisters although there was progress attributable to both genetic and nutrition influences.

We have conducted an additional experiment on supplementation of a 15 p.Ioo protein diet for dwarfs with levels of up to 0.I5 p. Ioo methionine which has not been reported yet. There was no apparent beneficial effect from levels above $0.05 \mathrm{p}$. Ioo dl-methionine. Fish meal at the level of 3 p. Ioo apparently meets the increased requirement for methionine in the diet of dwarf layers.

Currently we are conducting an experiment comparing diets based on different cereals with and without a supplement of 0.033 p. Ioo Protamone. Dwarf pullets fed diets supplemented with Protamone grew faster and ate more in the first four weeks than even normal size pullets but the effect gradually decreased and was negligible at $\mathrm{I} 6$ weeks of age. The level of 0.033 p. roo Protamone in the diet of layers depressed egg production and was subsequently reduced by one half.

\section{PHYSIOLOGY}

In the early years of our work with dwarfs we realized that a better understanding of their physiology, more specifically, the hormonal factors involved, would more precisely define their potential. We therefore undertook some studies with the kind cooperation of a colleague endocrinologist in the Department of Animal Science, Dr E. F. Eiling ToN, now at the University of Nebraska. The studies were begun in I966 and when completed the results were presented as a thesis by one of our graduate students, Mr. L. W. MrRosh, (r967) recipient of the Chester M. Wilcox Memorial Fellowship in Poultry Science. Two manuscripts incorporating the major results will be submitted for publication shortly (MIROsh, BERNIER, ELLINGTON, Arscotr and RowE, I97I). The study was conducted on I9 normal size and $2 \mathrm{I}$ dwarf pullets 2-3 months of age and 20 normal and 20 dwarf pullets $7-\mathrm{r}_{3}$ months of age. It was in two parts. One involved measurements of various endocrine glands and certain anatomical structures as shown in Tables 20-22. The second part involved the bioassay of the hypophyses of both types of birds at the two ages using hypophysectomized rats and the results are reported in Tables $23^{-25}$.

Normal chickens in both age groups were found to have significantly heavier hypophyses, thyroids, adrenals and ovaries than the dwarfs. These differences tended to disappear when the endocrine weights were expressed as a function of body weight, either absolute or metabolic body weight, except for the following instances. The relative weight of the hypophysis was significantly smaller in the older normals than in the other three groups of birds which could also indicate that the older dwarfs had a larger than expected hypophysis on a relative basis. The adrenals were significantly heavier in the older normals than in the other three groups which would indicate that the dwarfs did not have as large adrenals as would be expected. The relative weight of the thyroid was significantly heavier in the older normals than in the young normals while the reverse held for the dwarfs which had a relatively smaller thyroid as they grew older. The weight of the thyroid in the normal chickens almost doubled as they passed from the $2-3$ month to the $7-13$ month stage while that of the 
TABLE I7

Effect of protein, dl-methionine (Met), l-lysine (Lys) and safflower oil (SO) on egg production

Arscott and Bernier (1970)

Effet des protéines, de la dl-méthionine (Met.), de l-lysine (Lys.)

et de l'huile de cathame (SO) sur la production d'ceufs

Arscott et Bernier (1970)

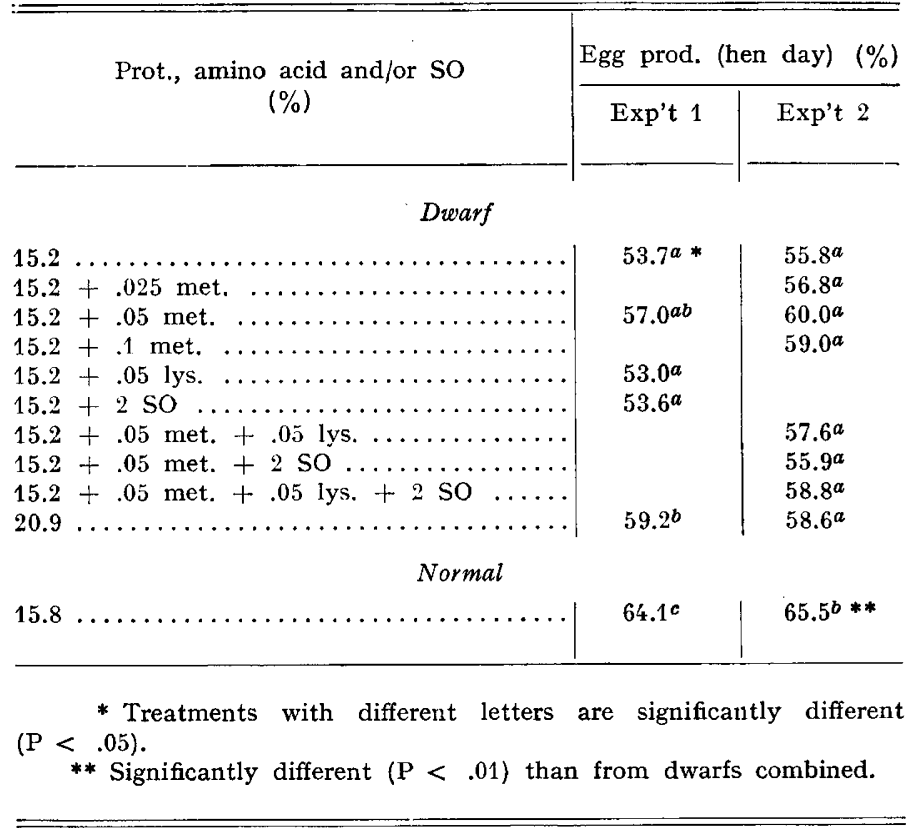

dwarfs changed very little which would lead to the hypothesis of hypothyroidism. This hypothesis is also supported by the histological characteristics of the thyroid. The epithelial cell height of the older dwarfs was significantly lower than that of the older normals and the young chickens of both types. The diameter of the colloid and the follicle were significantly higher in normals than in dwarfs of both ages.

It is tempting to explain sex-linked [recessive dwarfism by hypothyroidism. However the finding that such dwarfism is not overcome by the feeding of iodinated casein (van TIENHOVEN et al Ig66; BERNIER, I965, unpublished) nor by the injection of thyroxin (BERNIER, I965, unpublished) would argue against hypothyroidism as the the principal or sole factor involved. Notwithstanding these facts hypothyroidism as an explanation for sex-linked recessive dwarfism gains support from the histology of the thyroid as observed in this study and that of van TIENHOVEN et al. (1966). More recently, MÉRAT and GUILIAUME (I969) have reported smaller thyroids relative to body weight, a lower metabolism, reduced thyroid secretion, a higher percentage of abdominal fat, and a calmer disposition in dwarf birds than in normal size birds which led them to hypothesize hypothyroidism as associated with sex-linked recessive dwarfism. Whether or not alterations in pituitary thyrotropic activity are responsible 
for the thyroid disturbances observed in dwarfs could not be fully ascertained from the bioassay results of the hypophyses with hypophysectomized rats in this study. Of the four doses of chicken pituitaries, ranging up to as much as four pituitaries, only

TABLE I8

Effect of protein, dl-methionine, l-lysine and safflower oil on egg weight Arscott and Bernier (I970)

Effet des protéines, dl-méthionine, l-lysine et huile de carthame sur le poids des ceufs Arscott et Bernier (I970)

\begin{tabular}{|c|c|c|}
\hline \multirow{2}{*}{$\begin{array}{c}\text { Prot., amino acid and/or SO } \\
(\%)\end{array}$} & \multicolumn{2}{|c|}{ Egg wt. (g) } \\
\hline & Exp't 1 & Exp't 2 \\
\hline \multicolumn{3}{|l|}{ Dwarf } \\
\hline 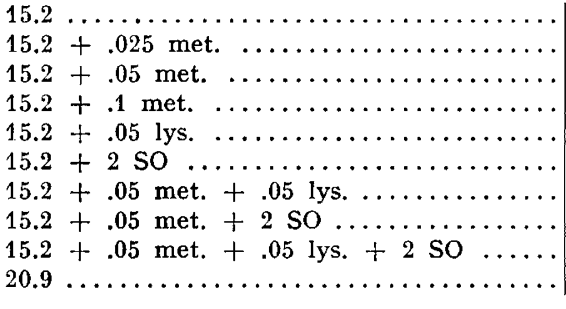 & $\begin{array}{l}51.7^{a *} \\
54.1^{b} \\
53.0^{a b} \\
53.3^{a b}\end{array}$ & $\begin{array}{l}54.7^{a b c} \\
55.5^{b c} \\
54.9^{b c} \\
54.9^{b c}\end{array}$ \\
\hline \multicolumn{3}{|l|}{ Normal } \\
\hline 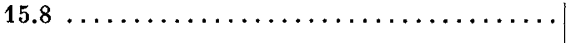 & $56.1^{c}$ & $57.2^{d}$ \\
\hline
\end{tabular}

* Treatments with different letters are significantly different $(\mathrm{P}<.05)$.

the highest dose originating from the normal chickens of both ages and from the older dwarfs brought about a significant weight response in the thyroids of hypophysectomized rats. Either the sensitivity of the rat thyroid to chicken thyrotropic stimulating hormone is low or the pituitary thyrotropic stimulating hormone is at a relatively low level in the chicken.

On the basis of pituitary cytological studies with sex-linked recessive dwarfism, van TIENHOVEN et al. (I966) have proposed that sex-linked recessive dwarfism is the result of a failure in the release of somatropic hormone from the pituitary. They found that the anterior pituitaries of dwarf chickens showed frequent recurrence of small cells with secretory droplets which they speculated to be the result of an accumulation of somatropic hormone because of a failure of its release into circulation. The pituitary bioassay results in our study do not support the contention of such an accumulation of somatropic hormone. Total pituitary STH content of dwarfs did not differ significantly from that of normals at either age studied. Nevertheless it is still possible that a decreased pituitary secretion of STH which would not neces- 
sarily be detected by a bioassay of only the pituitary glands could be a factor in dwarfism.

The possibility that ACTH and the adrenals may be involved in sex-linked recessive dwarfism must not be overlooked. The significant involvement of adrenal hor-

TABLE I9

Effect of protein, dl-methionine, l-lysine and safflower oil on feed per dozen eggs

Arscott and Bernier (r97o)

Effet des protéines, dl-méthionine, l-lysine et huile de carthame sur la consommation alimentaire par douzaine d'œufs

Arscott et Bernier (1970)

\begin{tabular}{|c|c|c|}
\hline \multirow{2}{*}{$\begin{array}{c}\text { Prot., amino acid and/or SO } \\
(\%)\end{array}$} & \multicolumn{2}{|c|}{ Feed per dozen eggs (lb) } \\
\hline & Exp't 1 & Exp't 2 \\
\hline \multicolumn{3}{|l|}{ Dwarf } \\
\hline 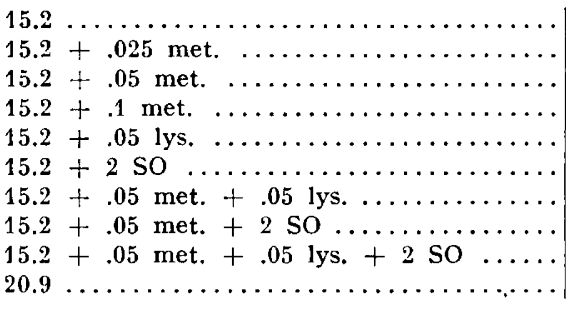 & $\begin{array}{l}3.97^{a *} \\
3.65^{a} \\
3.8^{a} a \\
3.81^{a}\end{array}$ & $\begin{array}{l}3.69^{a b c} \\
3.74^{a} \\
3.61^{a b c} \\
3.66^{a b c}\end{array}$ \\
\hline \multicolumn{3}{|l|}{ Normal } \\
\hline 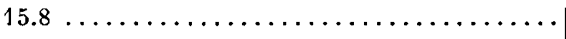 & $4.54^{b}$ & $4.45^{d}$ \\
\hline
\end{tabular}

* Treatments with different letters are significantly different $(\mathrm{P}<.05)$.

mones in pathways of carbohydrate, protein, and fat metabolism in mammalian species is well known and the same general conclusion is probably also valid for birds.

As compared to the normals, the pituitary ACTH activity of dwarfs was lower at 2-3 months of age but comparable at $7-\mathrm{I} 3$ months of age. Incidentally pituitary $\mathrm{ACTH}$ concentration for both types of birds appeared to be higher at the younger age than at the older one, as did STH concentration which may well be a reflection of involvement at a time when growth is rapid. The absolute adrenal weight was significantly less in the dwarfs than in the normals at the younger age but not at the older one. The difference at the younger age was removed by expressing the weight of the adrenals relative to both absolute and metabolic body weight. The older dwarfs had larger adrenals than older normals relative to absolute body size but not to metabolic body size. This difference may be the result of stresses associated with different nutritional requirements of the two types of birds, particularly protein as demonstrated in our nutrition studies. 


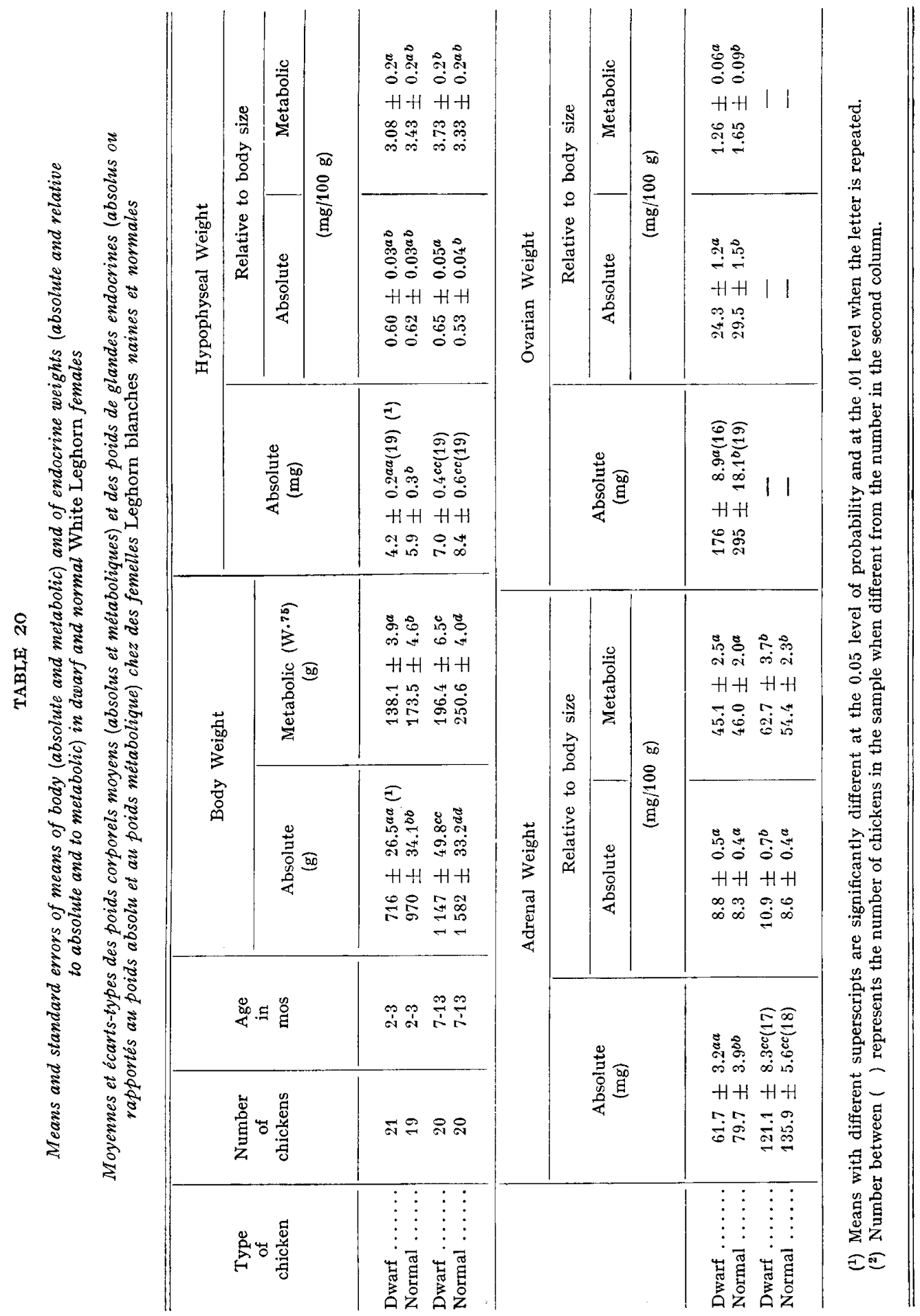




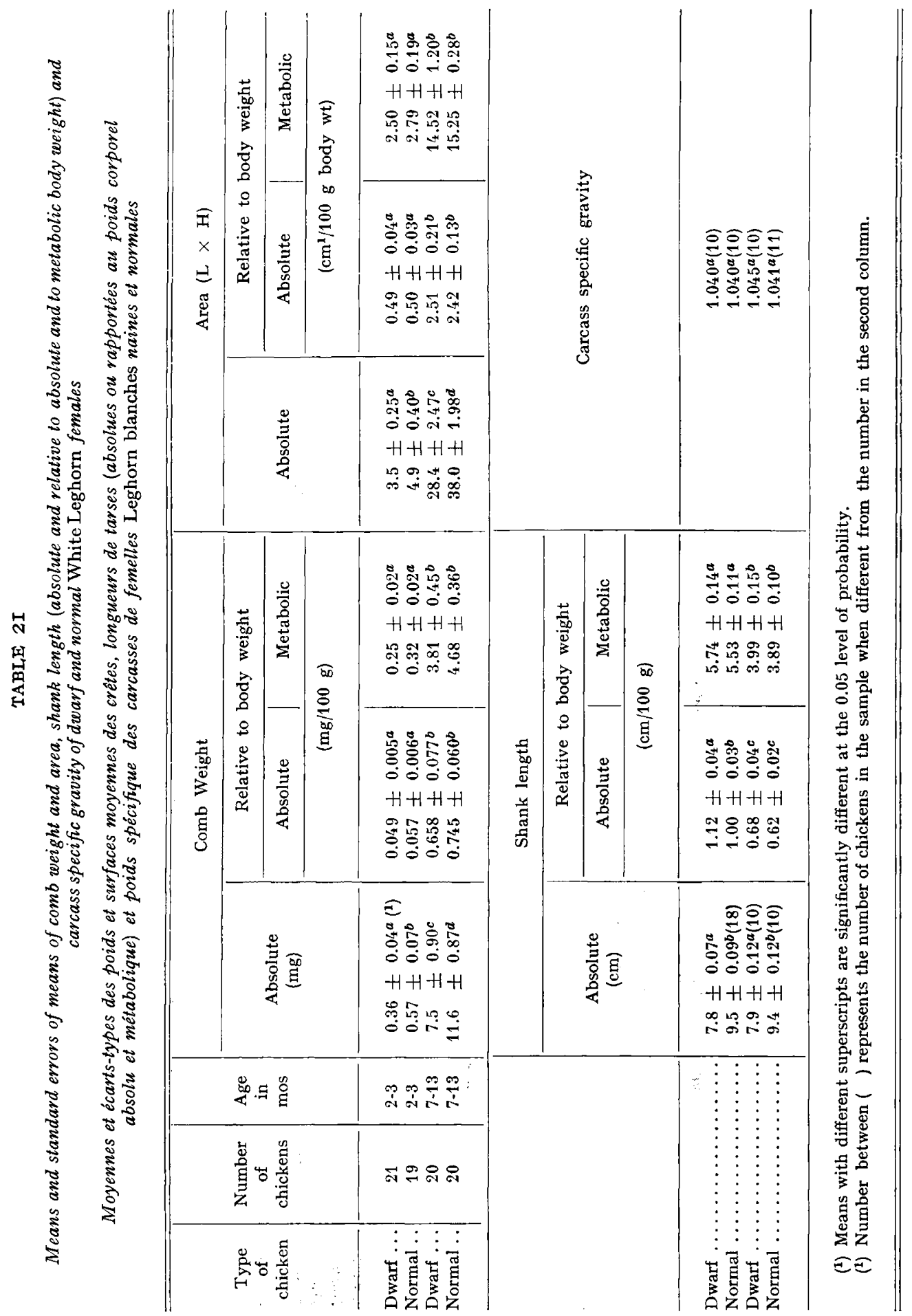


P. E. BERNIER, G. H. ARSCOTT

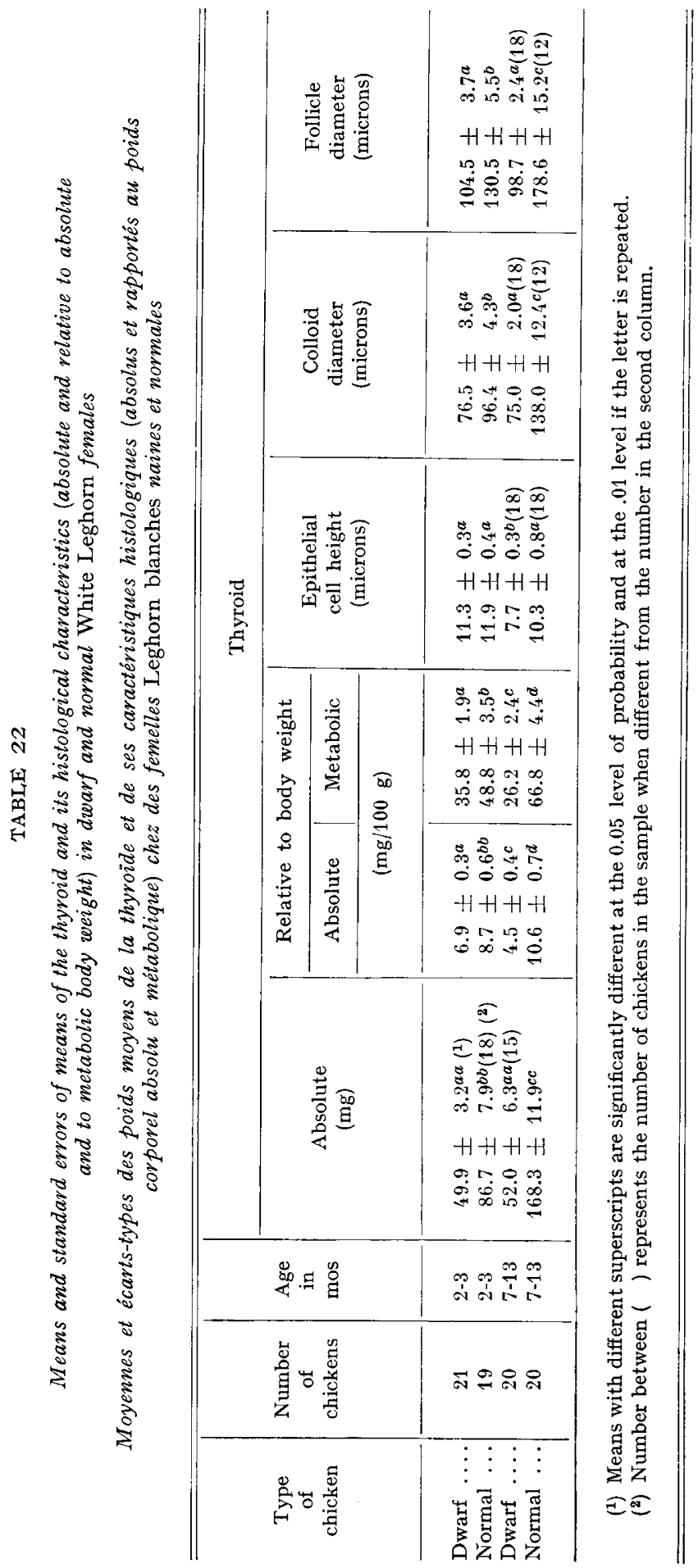




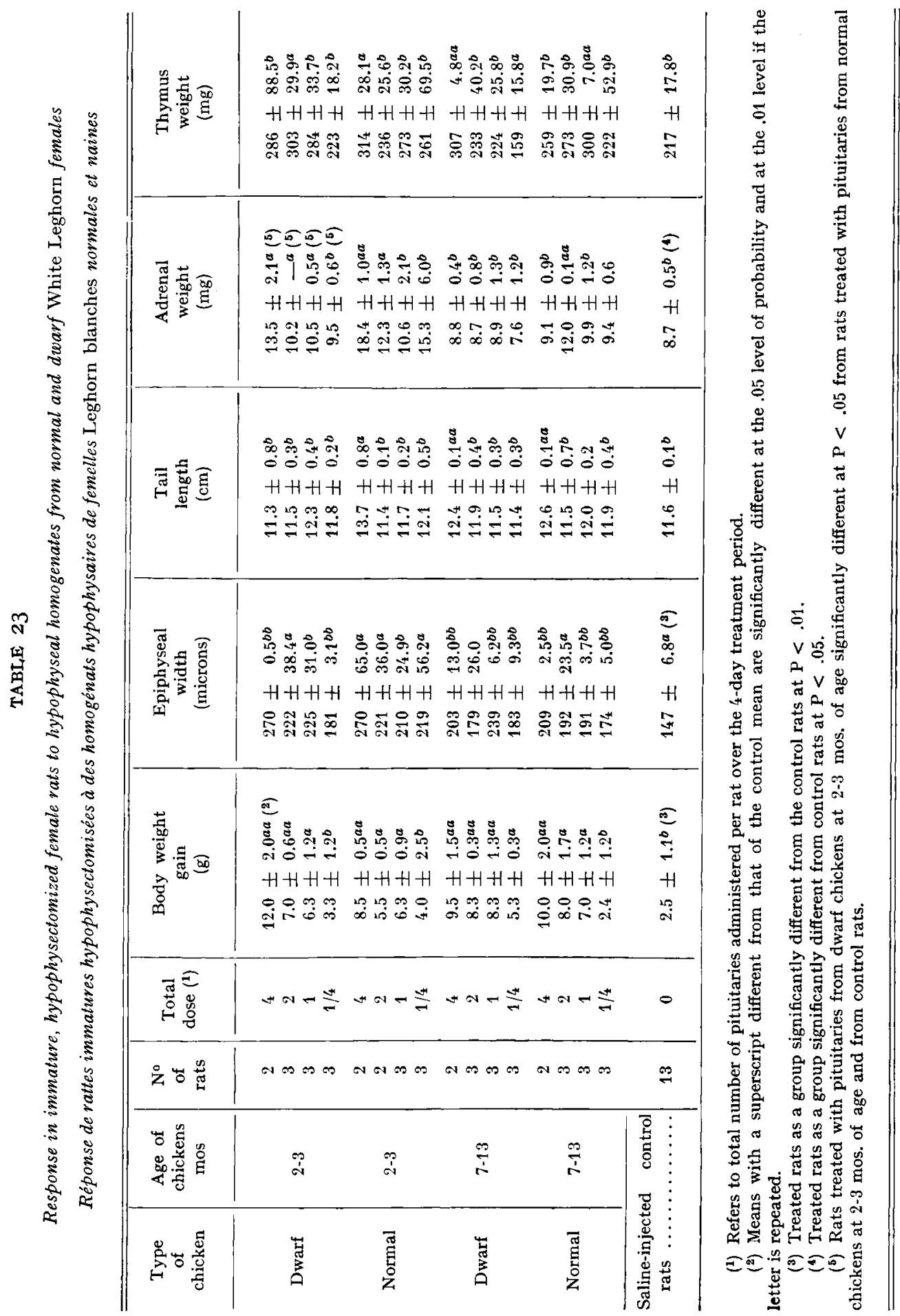



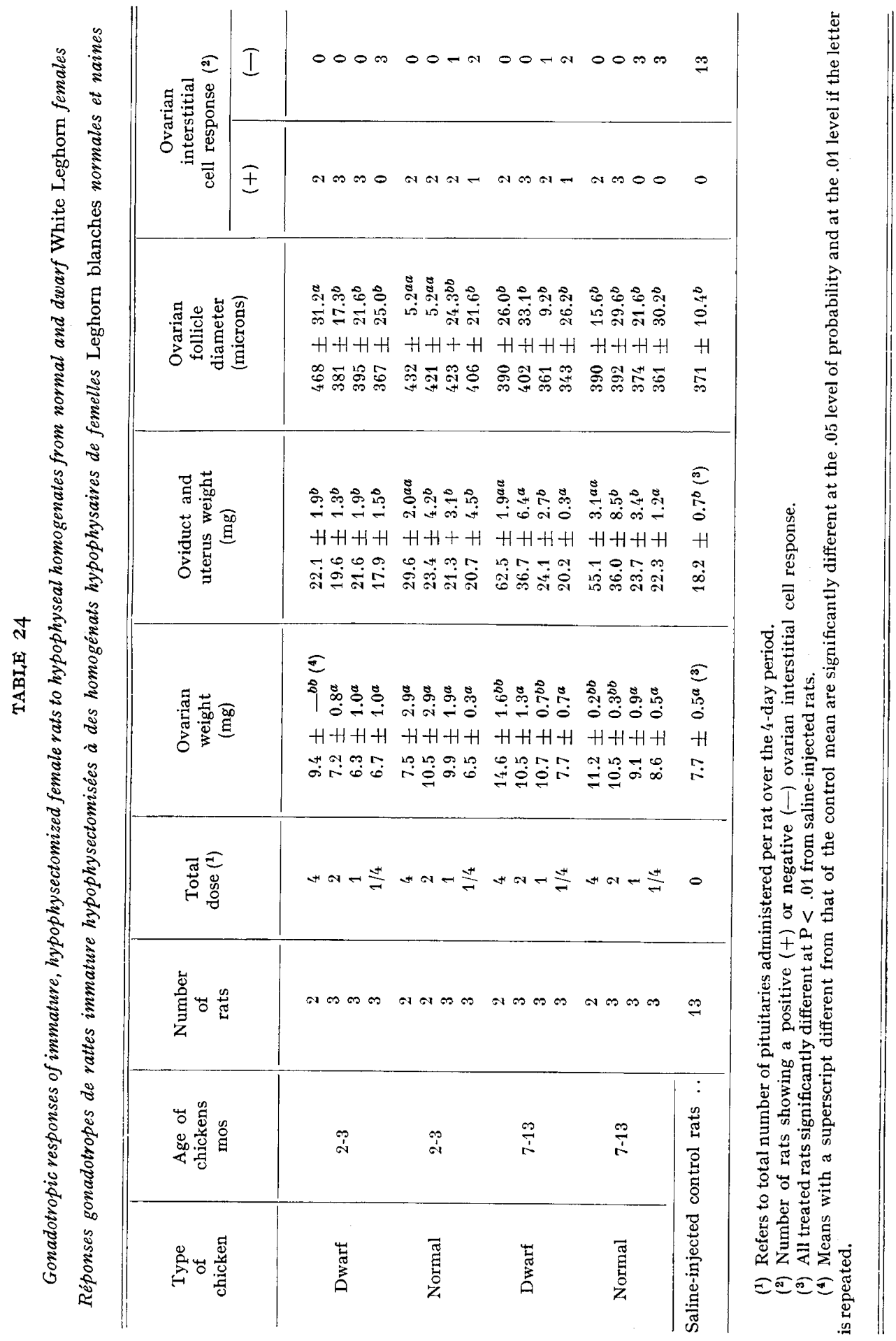


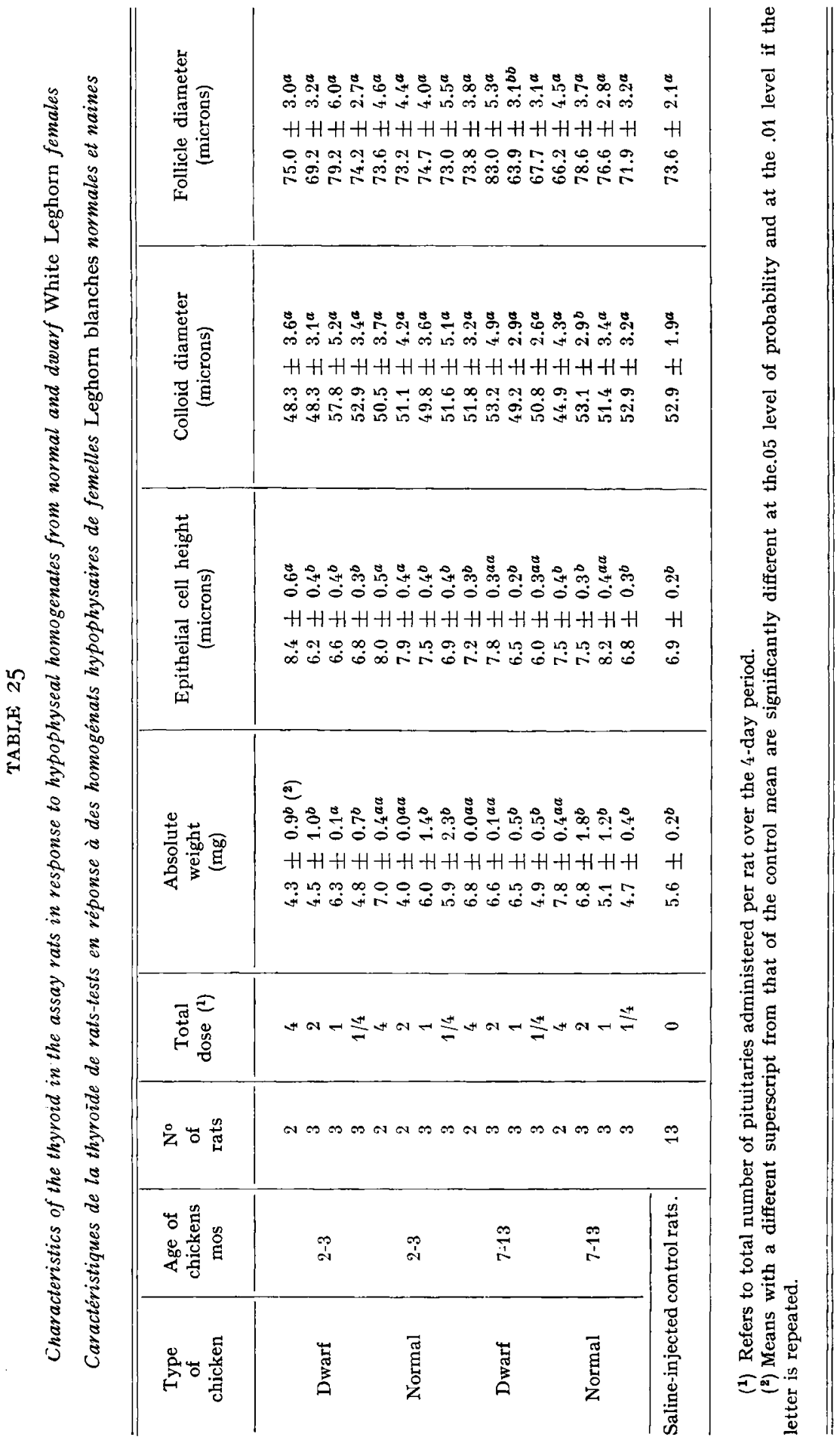


Gonadotropin content of the hypophyses of dwarf and normal chickens appeared comparable at both ages as evidenced by ovarian and uterine weight responses together with ovarian histological responses in the assay rats. There were no apparent differences in ovarian weight and in comb weight and area, comb size being an indirect reflection of ICSH activity. It is also of interest to note that van TIENHOVEN $e t$ al. (I966) were unable to find differences in the presumptive gonadotropic cells between the two types of chickens upon histological examination.

It would appear from the result of this study that sex-linked dwarfism may possibly involve more than one endocrine disturbance, possibly other endocrine structures not considered in the present study such as the pancreas. The development of procedures, such as radioimmunoassay, that allow detection of circulating levels of hormones from the pituitary will greatly facilitate progress in solving the problem.

Hormone administration, as has been done with thyroidal principles (van TIENHOVEn et al., I966 ; BERNIER, I965, unpublished) would appear to be a promising approach to study the endocrine basis of dwarfism. Because of the species specificity problem existing for protein hormones, it would be advisable to obtain such hormonal materials from chickens for experimental purposes. Unfortunately these materials are not, to our knowledge, readily available at the present time.

So much then for the evidence we have accumulated on the economic potential of dwarfism in egg production. Another area of great promise is that of management, more particularly housing density, or to paraphrase H. B. WALLACE (I970), oviduct density per square foot. We have not worked in that area but we were pleased to note a significant study by NoRDsKog \& BRIGGS (I968) which needs to be placed in its proper perspective to be fully appreciated. Before the advent of the broiler industry the profitability of an egg enterprise depended not on lyon egg production but also on the salvage value of body weight which meant reduced depreciation. There was also a general belief amongst poultrymen that body size was indicative of stamina because larger birds appeared to stand up better under conditions of stress. The evidence as reviewed by HuTr (I949) appeared to show a curvilinear relation between body weight and egg production altough the extensive data of TAYLOR (I930) collected in Canada supported a linear relation in Leghorns.

In the light of the popular belief and the experimental evidence relating heavier egg production in heavier Leghorns, the recent study of NoRDSKOG and BRIGGS (I968) elucidates the body-weight paradox as they termed it. They found that heavier birds stand up better under environmental stress but that smaller birds are genetically superior in egg production. There is thus an antagonism between the genetical and the environmental effects. In itself this antagonism justifies the trend to controlled environmental housing for egg production. We have noted in our work that minilayers withstand short periods of hot weather better than our normal size layers while the reverse is true in periods of cold weather.

We remain optimistic on the future of the minilayer for commercial egg production and we hope it eventually fulfills our great expectations. 


\section{RÉSUMÉ}

\section{QUINZE ANS D'OBSERVATIONS SUR LE GÈNE DE NANISME CHEZ LA POULE DOMESTIQUE}

Les observations sur le nanisme à la S. E. A. de l'Oregon remontent à I952, mais l'étude systématique n'a commencé qu'en r956. Des mutants nains ont été observés chez des Cornish et dans deux lignées consanguines de Leghorn et ont aussi été obtenus d'un accouveur local.

Une femelle mosaïque pour le nanisme et la taille normale a été observée dans la descendance de mâles nains accouplés à des femelles de taille normale. Cette femelle est génétiquement naine, toute la descendance l'étant. Un éperon s'est développé sur le tarse le plus grand. On suppose que le globule polaire contenant le chromosome sexuel porteur du gène pour la taille normale s'est réuni à l'une des deux cellules issues du premier elivage. Ceci a eu pour résultat une demi-femelle naine et un demi " neutre " triploïde de taille normale. L'analyse cytologique du sang et des follicules de plumes n'a pas révélé d'anomalie du caryotype.

Un létal récessif lié au sexe a été observé chez un mâle nain ayant une production de sperme exceptionnellement élevée. La moitié des embryons femelles issus du mâle porteur meurent très précocement et sont souvent classés comme infertiles. Des mâles nains accouplés à des femelles normales seraient un moyen commun d'obtenir des pondeuses naines, mais la disparité de taille pourrait éventuellement réduire le taux de fertilité dans les accouplements naturels.

Une proportion des mâles aux femelles de I à I 5 et de I à Io a donné jusqu'à cette année environ $80 \mathrm{p}$. I oo de fertilité. Une période d'au moins trois ou quatre semaines est apparue nécessaire pour atteindre ce niveau de fertilité, quoique celle-ci ait continué à augmenter lentement pendant 30-35 jours. Dans la période I 966-I97 I, les mâles ont été transférés directement de locaux sombres à des parquets éclairés avec les femelles. Cette année, les mâles étaient d'abord exposés à quinze heures de lumière pendant un mois avant d'être placés avec les femelles. La fertilité a augmenté beaucoup plus vite, atteignant 90 p. roo en I 5 jours, 95 p. Ioo en 2 I jours, mais la proportion était encore I mâle/Io femelles.

Les naines de lignée pure gardées en cages individuelles et reproduites par insémination artificielle ont montré une fertilité et un taux d'éclosion comparables à celles obtenues avec les femelles de taille normale.

Dans notre sélection génétique pour la production d'œufs des poules mises en poulaillers sur la base des performances individuelles et familiales, les résultats ont été pendant un certain temps désappointants. Ceci provient apparemment de ce que des polygènes pour l'hypothyroïdisme étaient en ségrégation par suite de la consanguinité qu'accompagnait notre sélection. L'âge au premier œuf a augmenté jusqu'à la valeur de 32,5 semaines, mais il a ensuite décru graduellement jusqu'à 24,3 semaines à la génération actuelle, ce qui représente encore une maturité de I,7 semaines plus tardive que dans notre lignée de production $O S U$.

La production des poules mises en poulailler a été assez décevante pendant un certain nombre d'années, mais elle a commencé à s'améliorer dans les trois dernières générations. Elle représente maintenant 83,4 p. Ioo de celle observée dans la lignée "Production "à 40 semaines d'âge. La taille des œufs a augmenté graduellement. Le poids corporel n'a pas changé à cause de la restriction à laquelle il était soumis dans notre sélection. Sinon, il aurait très vraisemblablement changé, comme réponse liée à notre sélection pour la taille des œufs.

Des études de nutrition ont été conduites avec des populations d'effectif allant de 240 animaux les premières années à plus de 1200 pondeuses naines dans les années plus récentes, par groupes de 6o. Nous avons mis en évidence le fait que les poulettes naines, même compte tenu de leur maturité sexuelle retardée, ont besoin d'une quantité d'aliments plus faible pour atteindre l'âge de la ponte. Les études de nutrition ont porté sur l'influence :

I. Des taux de calcium.

2. Du doublement du taux normal de vitamines et d'oligoéléments.

3. Du taux protéique jusqu'à 21 p. roo.

4. De la supplémentation en méthionines lysine et acide linsléique.

Quoique la production d'œufs ait plafonné à partir du taux protéique de I $5 \mathrm{p}$. Ioo, la taille des œufs a continué à augmenter jusqu'à 21 p. roo. L'addition de 0,05 p. roo de méthionine a augmenté la ponte et le poids des œufs significativement et à des niveaux comparables à ceux observés avec une ration à 2 I p. Ioo de protéines. Actuellement, un faible taux de protamone est donné aux pondeuses élevées avec ou sans supplément de protamone, mais ce taux a dû être réduit de moitié, jusqu'à 0,0167 p. IOo, car il abaissait la ponte. 
Les études physiologiques ont inclus l'observation des hypophyses, thyroïdes, surrénales et ovaires, à la fois pour des femelles en croissance et adultes, ainsi qu'un test biologique d'homogénats hypophysaires sur des rates immatures hypophysectomisées. Quoique les thyroïdes des femelles naines soient apparues plus petites que celles des normales à $7-\mathbf{I} 3$ mois d'âge, le test biologique n'a pu prouver que les modifications thyroïdiennes chez les naines soient dues à des altérations de l'activité thyréotrope de leur hypophyse.

Le résultat du test biologique des hypophyses ne confirme pas l'hypothèse de l'accumulation d'hormone somatotrope dans les hypophyses d'oiseaux nains. L'observation de l'ACTH et de l'activité gonadotrope a été faite aussi sur les hypophyses de naines.

\section{REFERENCES}

Abstracted in World Poult. Sci. J., 1971, 27, 279-281 and in the present journal (1971, 3).

Arscott G. H., Rachapaetayakom P., Bernier P. E., I96r. Observations on gross requirements for certain nutrients in dwarf White Leghorn hens. Poult. Sci., 40, I372-1373.

Arscott G. H., Rachapaetayakom P., Bernier P. E., Adams F. A., r962. Influence of ascorbic acid, calcium and phosphorus and specific gravity of eggs. Poult. Sci., 41, 485-488.

ARSCOTT G. H., BERnIER P. E., I968. Effect of dietary protein on performance of dwarf White Leghorn layers. Poult. Sci, 47, I652.

Arscott G. H., Bernier P. E., I97o. Protein and amino acid needs of the mini-hen. Proc. 5th Ann. Pacific Northwest Animal Nutrition Conference, Richland, Washington, November 12-13, 1970, 5, 52-59.

Bernier P. E., 1953. A dominant lethal in S. C. White Leghorns. Poult. Sci., 32, 889-89o.

Bernier P. E., I96o. A spontaneous chromosome aberration in a S. C. White Leghorn. Poult. Sci. 39, 1234.

Bernier P. E., I96o. Midget layers-a progress report. Proc. Eighteenth Annual Oregon Animal Industry Conference, I960, 23-24.

Bernier P. E., Arscott G. H., Ig6o. Relative efficiency of sex-linked dwarf layers and their normal sisters. Poult. Sci., 39, I234-1235.

Bernier P. E., Arscott G. H., 1966. Growth and feed requirements of dwarf White Leghorn pullets compared to their normal-size sisters. Poult. Sci., 45, ro7o.

Bernier P. E., Arscott G. H., I968. Some economical and nutritional implications of minilayers. Proc. 3rd Ann. Pacific Northwest Animal Nutrition Conference, Harrison Hot Springs, B. C., Canada November 7-8, 1968, 3, 47-53.

Bird S., Sinclair J. W., I939. A study of the energy required for maintenance, egg production, and changes in body weight in the domestic hen. Sci. A gri., 19, 542-55o.

BYERLY T. C., I94I. Feed and other costs of producing market eggs. Maryland Agric. Exp. Station Bulletin $A l$ (Tech.).

COLE R. K., 1966. Hereditary hypothyroidism in the domestic fowl. Genetics, 58, I02I-I033.

Crew, F. A. E., Munro S. S., 1938. Gynandromorphism and lateral asymmetry in birds. Proc. Roy. Soc. (Edinburgh), 58, Pt. II, Ir4-I34.

Crew F. A. E., Munro S. S., 1939. Lateral asymmetry in the fowl. Proc. 7th World's Poultry Congress (Cleveland), 6r-64.

FEsting M. F., Nordskog A. W., x967. Response to selection for body weight and egg weight in chickens. Genetics, 55, 2I9-231.

Hollander W. F., I944. Mosaic effects in domestic birds. Quart. Rev. Biol., 19, 285-307.

Hutr F. B., I949. Genetics of the fowl, MacGraw-Hill.

Hut F. B., I953. Sex-linked dwarfism in the fowl. Genetics, 38, 670.

Hutr F. B., I959. Sex-linked dwarfism in the fowl. J. Hered., 50, 209-221.

KEARL C. D., I957. Layer feed utilization efficiency-where is it? Farm Economics (Cornell), $202: 5576$.

Merat P., Guillaume J., Ig69. Étude d'un gène de nanisme lié au sexe chez la poule. II. Fonctionnement thyroïdien. Ann. Génét. Sél. Anim., 1, I3I-I33.

Mirosh L. W., Bernier P. E., Ellington E. F., Arscott G. H., Rowe K. E., 1972. Some hormonal factors in sex-linked recessive dwarfism of the White Leghorn chicken. Probably Poultry Science.

Mirosh L. W., I967. Endocrinology of sex-linked recessive dwarf White Leghorn chickens, Gallus domesticus, with special reference to the thyroid., Oregon State University. M. Sc. Thesis.

Nordskog A. W., Briggs D. M., rg68. The body weight egg production paradox. Poult. Sci., 47, 498-504.

RYAN W. C., BERNier P. E., r968. Cytological evidence for a spontaneous chromosome translocation in the domestic fowl. Experientia, 24,623-624. 
TAYLOR A. G., I930. Report of the ninth and tenth annual Canadian National Egg Laying Contests. Canada. Department of Agriculture Bulletin 139 (n. s.).

Tienhoven van A., Williamson J. H., Tomlinson M. C., Macinnes K. L., ig66. Possible role of the thyroid and the pituitary glands in sex-linked dwarfism in the fowl. Endocrinology, 78, 950-957.

Wallace H. B., I970. The egg industry. A look into the 7o's. Canadian Poultry Review, 94, 23-24, $26-27,38,39-42$. 